Article

\title{
Proposing a Novel Predictive Technique for Gully Erosion Susceptibility Mapping in Arid and Semi-arid Regions (Iran)
}

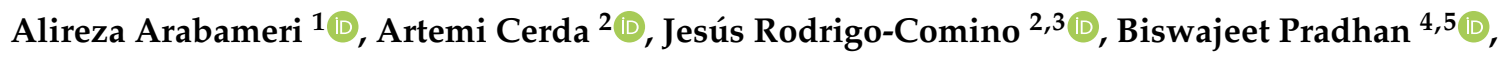 \\ Masoud Sohrabi ${ }^{6}$, Thomas Blaschke ${ }^{7}$ and Dieu Tien Bui ${ }^{8, * \text { (D) }}$ \\ 1 Department of Geomorphology, Tarbiat Modares University, Tehran 36581-17994, Iran; alireza.arab@ut.ac.ir \\ 2 Soil Erosion and Degradation Research Group, Departament de Geografia, Universitat de València, \\ Blasco Ibàñez, 28, 46010 Valencia, Spain; artemio.cerda@uv.es (A.C.); rodrigo-comino@uma.es (J.R.-C.) \\ 3 Physical Geography, Trier University, 54286 Trier, Germany \\ 4 Centre for Advanced Modelling and Geospatial Information Systems (CAMGIS), Faculty of Engineering and \\ Information Technology, University of Technology Sydney, Sydney, 2007 New South Wales, Australia; \\ biswajeet.pradhan@uts.edu.au \\ 5 Department of Energy and Mineral Resources Engineering, Sejong University, Choongmu-gwan, \\ 209 Neungdong-ro, Gwangjingu, Seoul 05006, Korea \\ 6 Department of Civil Engineering- geotechnics, Islamic Azad University of Urmia, Urmia 5167678747, Iran; \\ m.sohrabi@iaurmia.ac.ir \\ 7 Department of Geoinformatics - Z_GIS, University of Salzburg, 5020 Salzburg, Austria; \\ thomas.blaschke@sbg.ac.at \\ 8 Institute of Research and Development, Duy Tan University, Da Nang 550000, Vietnam \\ * Correspondence: buitiendieu@duytan.edu.vn
}

Received: 26 September 2019; Accepted: 1 November 2019; Published: 2 November 2019

check for updates

\begin{abstract}
Gully erosion is considered to be one of the main causes of land degradation in arid and semi-arid territories around the world. In this research, gully erosion susceptibility mapping was carried out in Semnan province (Iran) as a case study in which we tested the efficiency of the index of entropy (IoE), the Vlse Kriterijumska Optimizacija I Kompromisno Resenje (VIKOR) method, and their combination. Remote sensing and geographic information system (GIS) were used to reduce the time and costs needed for rapid assessment of gully erosion. Firstly, a gully erosion inventory map (GEIM) with 206 gully locations was obtained from various sources and randomly divided into two groups: A training dataset (70\% of the data) and a validation dataset (30\% of the data). Fifteen gully-related conditioning factors (GRCFs) including elevation, slope, aspect, plan curvature, stream power index, topographical wetness index, rainfall, soil type, drainage density, distance to river, distance to road, distance to fault, lithology, land use/land cover, and soil type, were used for modeling. The advanced land observing satellite (ALOS) digital elevation model with a spatial resolution of $30 \mathrm{~m}$ was used for the extraction of the above-mentioned topographic factors. The tolerance (TOL) and variance inflation factor (VIF) were also included for checking the multicollinearity among the GRCFs. Based on IoE, we concluded that soil type, lithology, and elevation were the most significant in terms of gully formation. Validation results using the area under the receiver operating characteristic curve (AUROC) showed that IoE (0.941) reached a higher prediction accuracy than VIKOR (0.857) and VIKOR-IoE (0.868). Based on our results, the combination of statistical (IoE) models along with remote sensing and GIS can convert the multi-criteria decision-making (MCDM) models into efficient and powerful tools for gully erosion prediction. We strongly suggest that decision-makers and managers should use these kinds of results to develop more consistent solutions to achieve sustainable development on degraded lands such as in the Semnan province.
\end{abstract}

Keywords: remote sensing; land degradation; sustainable development; statistical model; gully erosion; land management 


\section{Introduction}

Various forms of water-related erosion are known, of which gully erosion is one of the most destructive types [1]. Gullies are able to destroy the surface and sub-surface horizons of the soil and cause the deformation of the land, generating massive economic damage to humankind, such as through the destruction of agricultural land, infrastructure, ecosystems, and desertification, and by intensifying the discharge of surface runoff, causing a fall in the groundwater level and creating environmental hazards such as floods [2-4]. Therefore, gully erosion results in many socio-economic problems and can threaten the sustainable development of countries [5]. There is a worldwide agreement to fight land degradation [6-9]; however, there has not been much work carried out to this end.

According to the definitions given by the pioneer investigations about gullies [10-14], the depth and width of a specific gully can range from $30 \mathrm{~cm}$ to several meters, and its length can reach up to several hundred meters. The shape of a gully is constructed from the result of its formation processes; thus, the first step in examining these processes is to study the gully shape [15]. Accordingly, some scientists divided gullies into different groups. Ireland et al. [10] categorized the forehead of the gully into four groups: Pointed, rounded, notched, and digitized. Furthermore, they divided the linear profiles of the gully forehead into four categories: Inclined, vertical, cave, and cave with overhanging root mat or sod.

On the other hand, Morgan [16] divided the gullies according to their cross-sectional shape. They corroborated that $\mathrm{V}$-shaped gullies can be caused by surface runoff processes in hardpan areas, whereas U-shape types are formed through the sub-surface or surface mechanisms in loose areas. Compared to rivers that have a smooth, long, and concave profile, gullies are distinguished by features such as the presence of a vertical wall in the head and dropped points along the bed [11].

Zaimes and Schultz [17] divided gullies into four classes; (i) classic continuous, (ii) classic discontinuous, (iii) ephemeral continuous, and (iv) ephemeral discontinuous. Classic gullies are defined as channels with depths ranging from 0.5 to $30 \mathrm{~m}$ that common farm equipment cannot ameliorate, while ephemeral gullies are defined as shallower channels that tillage can erase but often leave gentle swales [18]. Continuous gullies are connected to the stream channel and gain depth rapidly after the head-cut while maintaining a constant gradient near the mouth of the gully that reaches the stream channel [19]. Discontinuous gullies do not reach the stream channel, and the gully depth decreases from the head-cut [19].

Gully erosion is a threshold-based phenomenon and would not occur until the factors exceed the threshold limit [20]. The main factors in the development of a gully are the existence of an accumulated runoff at the surface of the soil or underground erosion and the fall of the roof of this type of erosion, in which the topographical and geological conditions determine these two factors [21]. Human factors, such as land use changes resulting from population growth, degradation of forests and pastures, reduction of vegetation, and extension of residential areas and communication paths caused by fundamental changes in the natural hydrological conditions of the watersheds, intensify the gully erosion [22]. Historical studies on gully erosion indicate that, in the last decade, severe changes in the trend of gully erosion occurred due to inappropriate land management, non-standard cultivation, and severe and fast land use changes [23]. The main prerequisite for dealing with various types of erosion, especially gully erosion, is the prediction of the risk of gully formation in different areas that are prone to this type of erosion [24].

Over the last decades, with the advent of powerful processor systems such as the GIS (geographic information system), a wide variety of methods have been tested to identify areas that are susceptible to gully erosion around the world, and have achieved very acceptable results $[25,26]$. These models can include (i) expert knowledge-based models such as the analytic hierarchy process (AHP) [27]; (ii) bivariate and statistical-based models such as the frequency ratio (FR) [28], conditional probability (CP) [29], evidential belief function (EBF) [17], information value (IV) [30], certainty factor (CF) [31], index of entropy (IoE) [32], logistic regression (LR) [33-36], weights-of-evidence (WOE) [37], and 
maximum entropy (ME) [27,38,39]; and, (iii) machine learning models such as artificial neural network (ANN) [40], boosted regression tree (BRT) [41], multivariate adaptive regression spline (MARS) [42], random forest (RF) [43], linear discriminant analysis (ADA) [44], naïve Bayes tree (NBTree) [45], and classification and regression trees (CART) [41].

In arid and semi-arid climates, such as the Semnan province, Iran, gullies cause very extensive damage and are considered a major environmental problem $[26,46]$. Therefore, the identification of the causes of gully erosion development and its zoning for comprehensive management planning by executive agencies remain essential. This will be definitive to the design of restoration strategies that can be developed following nature-based solutions to achieve sustainability [47]. Our literature review to date shows that despite the high sensitivity of this study area to gully erosion, no comprehensive studies have been carried out to identify areas that are particularly susceptible to gully erosion at all; although the scientific community are working very hard and achieving interesting and promising results. In this study, a new hybrid approach has been used to identify areas susceptible to gully erosion, which includes the combination of MCDM (multi-criteria decision making) and bivariate statistical methods. The main objective of this research is the development of a gully erosion susceptibility mapping in a representative area with known soil erosion processes; in this case, the Semnan province in Iran. To this end, the efficiency of the index of entropy (IoE) as a statistical model, Vlse Kriterijumska Optimizacija I Kompromisno Resenje (VIKOR) as multi-criteria decision-making model, and the combination of the two methods were assessed in terms of their suitability for prediction of areas prone to gully erosion.

\section{Materials and Methods}

\subsection{Study Area}

The Semnan watershed with an area of $8700 \mathrm{~km}^{2}$ is located in the western part of Semnan province $\left(52^{\circ} 37^{\prime} 19^{\prime \prime}\right.$ to $54^{\circ} 06^{\prime} 25^{\prime \prime}$ E longitude and $34^{\circ} 52^{\prime} 40^{\prime \prime}$ to $35^{\circ} 51^{\prime} 04^{\prime \prime} \mathrm{N}$ latitude) (Figure 1 ). The minimum elevation of the study area is $743 \mathrm{~m}$.s.a.l. the maximum elevation is 3266 m.s.a.l. and the mean elevation lies at $1184 \mathrm{~m} . s . a . l$. The mean annual rainfall is $120 \mathrm{~mm} / \mathrm{year}$, and the average annual temperature is $21.8^{\circ} \mathrm{C}$, which is considered a dry and semi-arid climate [48]. The inclination of the study area varies from a minimum of $0^{\circ}$ to a maximum of $73^{\circ}$, with mean values of $51.5^{\circ}$. The topography of the Semnan watershed can be considered mostly flat in the central and southern parts, and the northern area has a mountainous landscape. The most important settlements in the study area are Semnan, Sorkheh, Mahdishahr, and Shahmirzad. The soils of the study are mainly in the group of plateau soils and can be classified as Inceptisols, Entisols, and Aridisols [49]. The lithology units in the study are mostly marls, gypsum, conglomerate, sandstone, shale, tuff, dolomite, limestone, fluvial conglomerate, volcanic rocks, clays, and saline areas [50]. The main land uses are cultivated areas, bare lands, kavir, mid-range, poor-range, urban, and waterbodies.

Morphometric analysis of gullies in the study area shows that about $8 \%$ of the study area could be affected by severe soil erosion, which would indicate a high sensitivity of the study area to the development of gully erosion processes. The abundance of gullies in the center and south of the study area with a low slope is higher, while, in contrast, the northern parts of the study area features more steep slopes and the rocky outcrops. A first overview shows that gully lengths range from several to hundreds of meters with depths reaching some meters. The width of the gullies also can vary from several centimeters to meters. We observed that the cross-section of the detected gullies in the northern parts is mainly V- shape, but in the central and southern parts, possibly due to the more erodible and lower slopes, they are U-shaped. In terms of the position of the gully in the landscape, most of the gullies are on the floor valley type. Considering the evolution of their morphologies [15], the gullies are mostly of a continuous type (drainage network), and the rest are discontinuous ones. 
In terms of the head-cut plan [10], the gullies in the study area could be classified as a digitized type. They have a maximum width of $8 \mathrm{~m}$, a maximum depth of $12 \mathrm{~m}$, and a maximum length of $360 \mathrm{~m}$. The expansion of these corridors and the fall of their roofs are causing an increase in their sizes.

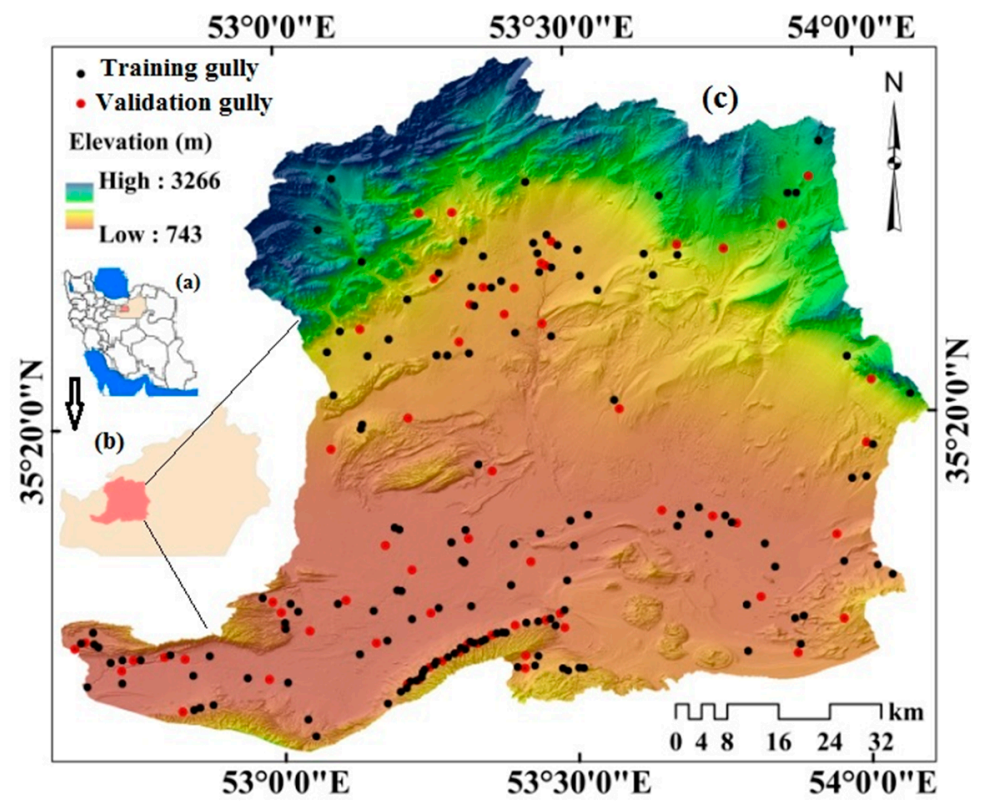

Figure 1. Study area and location of the gullies. (a) Location of the Semnan province and study area in Iran; (b) location of the study area in the Semnan province. (c) Location of training and validation gullies in the study area.

\subsection{Methodology}

As shown in Figure 2, this research consists of five different steps. Firstly, the data were prepared, which consisted of 3 steps: (i) Determining the location of the gullies in the study area, preparing a gully erosion inventory map (GEIM) and dividing the data into two groups, namely training data $(70 \%)$ and validation data (30\%); (ii) selecting 500 sample points (alternatives) in the study area for applying the VIKOR model using the tool "Create random point" in ArcGIS10.5 (ESRI, USA); and, (iii) including the gully-related conditioning factors (GRCFs), which was divided into the four groups of topographical (slope, aspect, elevation, plan curvature, and topography wetness index (TWI)), geological (lithology and distance to fault), hydrological (stream power index (SPI), rainfall, drainage density, and distance to stream), and environmental (distance to road, soil type, normalized difference vegetation index (NDVI), and land use/land cover (LU/LC)) factors. Secondly, an assessment of the multicollinearity among the conditioning factors was performed. In the third step, the index of entropy (IoE) and the VIKOR (VIseKriterijumska Optimizacija I Kompromisno Resenje) models were applied. The fourth step aimed to introduce a novel hybrid model through the integration of the IoE and VIKOR models (IoE-VIKOR) for gully erosion susceptibility mapping (GESM). Finally, in the fifth step, a validation of the models was performed using the seed cell area index (SCAI) and the area under the curve (AUC). 


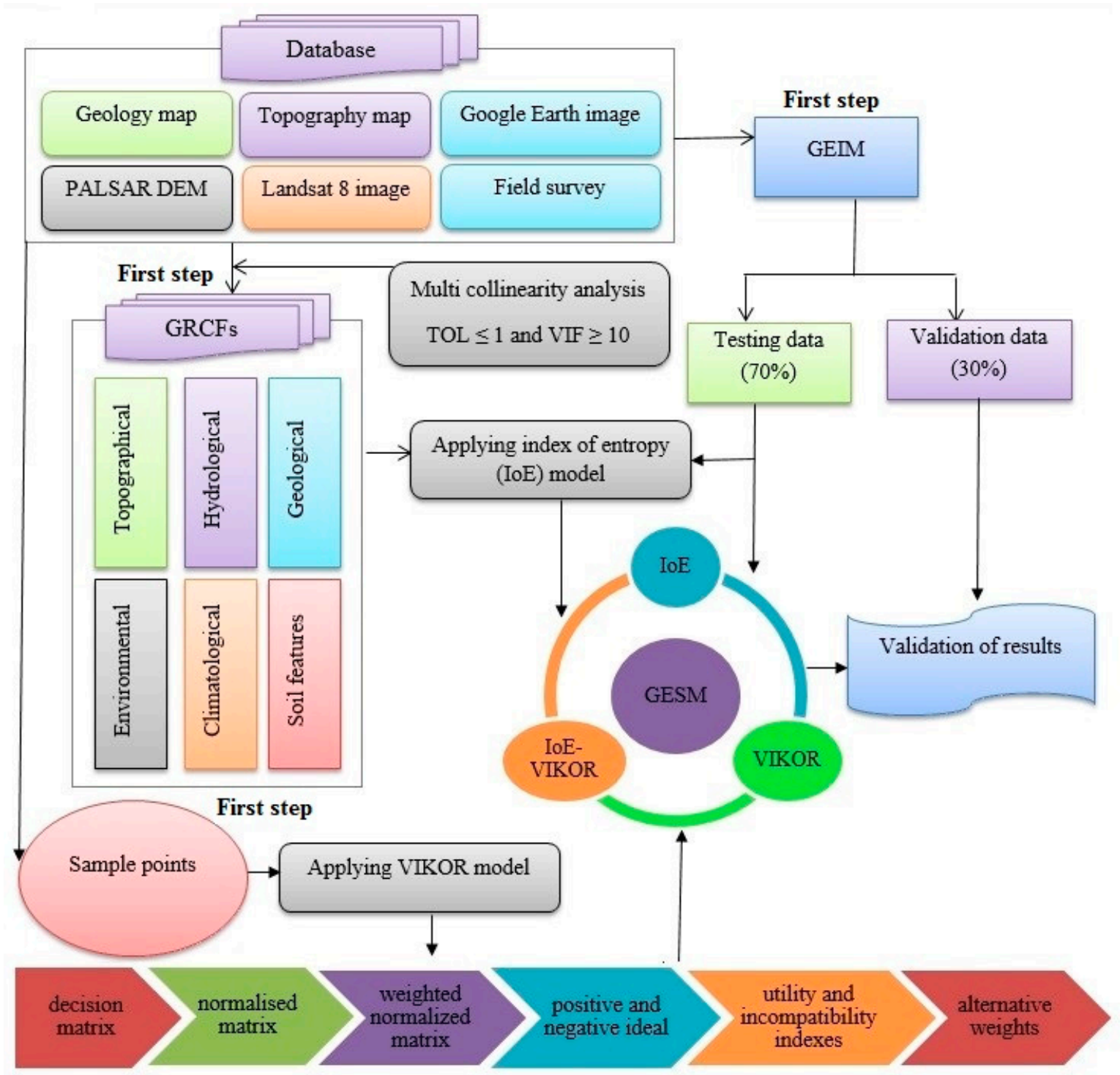

Figure 2. Methodology of research conducted for the study area.

\subsection{Data Preparation}

\subsubsection{Gully Erosion Inventory Map}

For gully erosion susceptibility mapping (GESM), a map of the spatial distribution of the considered gullies is a prerequisite [51-53]. The gully erosion inventory map was prepared from the data provided by the Agricultural and Natural Resources Research Center of Semnan Province. In order to complete inventory map, the interpretation of satellite images and extensive field surveys were conducted in the study area. A total of 206 gully plots were identified in the study area (Figure 1). In the next step, the head-cuts of the gullies were converted to points and were used to build the gully erosion susceptibility model $[7,9,29,31,40,51,53]$. Finally, the gullies were randomly divided into two groups, with $70 \%$ of points used for modeling (145 gullies) and 30\% used for validation (61 gullies) [41,52]. One of the identified gullies in the study area is shown in Figure 3. 


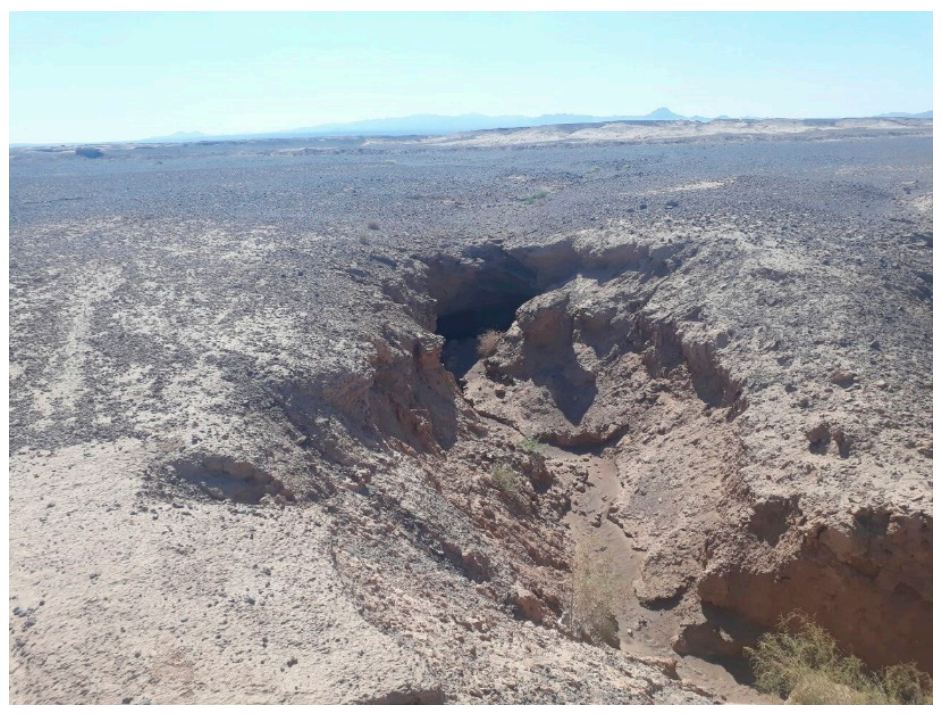

Figure 3. Head-cut of some of the mapped gullies in the study area.

\subsubsection{Gully-Related Conditioning Factors (GRCFs)}

In general, various GRCFs affect the occurrence of gully erosion in different regions based on different environmental conditions [18]. In the current study, our 15 GRCFs were: Elevation, slope, aspect, plan curvature, stream power index (SPI), topography wetness index (TWI), rainfall, soil type, drainage density, distance to river, distance to road, distance to fault, lithology, land use/land cover (LU/LC), and normalized difference vegetation index (NDVI) (Figure 4a-o). These factors were determined based on a literature review [41,51,52], physiographic features of the study area, the expert knowledge of natural resources experts of Semnan and Isfahan provinces, and a multicollinearity test.

Topographic parameters, namely elevation, slope degree, slope aspect, plan curvature, and TWI, and the hydrological parameters of SPI, drainage density, and distance to stream, were extracted from ALOS (the advanced land observing satellite), PALSAR (the phased array type L-band synthetic aperture radar), and a DEM (digital elevation model) with a spatial resolution of $12.5 \mathrm{~m}$.

The SPI is a factor considered for the measurement of the erosive power of water runoff [30]. The SPI was obtained as per Equation (1) [54]:

$$
\mathrm{SPI}=\mathrm{As} \times \tan \sigma
$$

where $A s$ is the specific catchment area in meters and $\sigma$ is the slope gradient in degrees. The TWI is a parameter that plays a crucial role in gully occurrence, and was calculated as per Equation (2) [54]:

$$
\mathrm{TWI}=\operatorname{In}\left(\frac{\mathrm{S}}{\tan \alpha}\right)
$$

where $S$ is the cumulative upslope area draining through a point and $a$ is the slope gradient in degrees. In this research, the stream network affected gully occurrence. The distance to streams and drainage density are calculated after the extraction of the stream network from the DEM in Arc Hydro using the Euclidean distance and line density in spatial analysis tools in ArcGIS [37].

The road and fault factor maps, with scales of 1:50,000 and 1:100,000, respectively, were obtained from the National Geographic Organization of Iran (www.ngo-org.ir) and the Geological Society of Iran (GSI) (http://www.gsi.ir/), respectively.

The NDVI was computed from the LANDSAT-8 image archived by USGS (https://earthexplorer. usgs.gov/) with $30 \mathrm{~m}$ spatial resolution. The NDVI map of the study area was produced using Equation (3):

$$
\mathrm{NDVI}=\mathrm{NIR}-\mathrm{R} / \mathrm{NIR}+\mathrm{R}
$$


where NIR is the infrared portion of the electromagnetic spectrum (band 5) and R is the red portion of the electromagnetic spectrum (band 4).

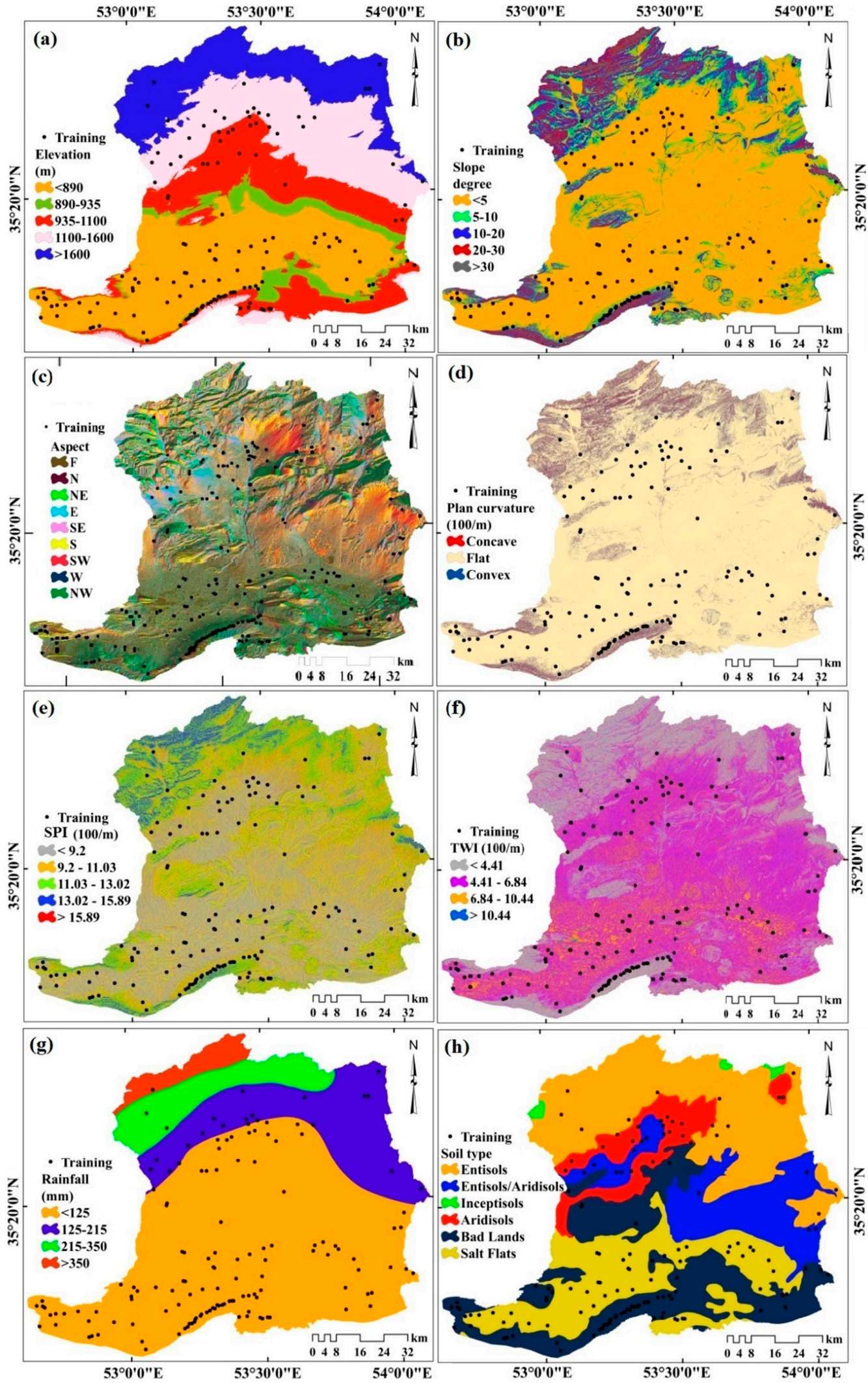

Figure 4. Cont. 

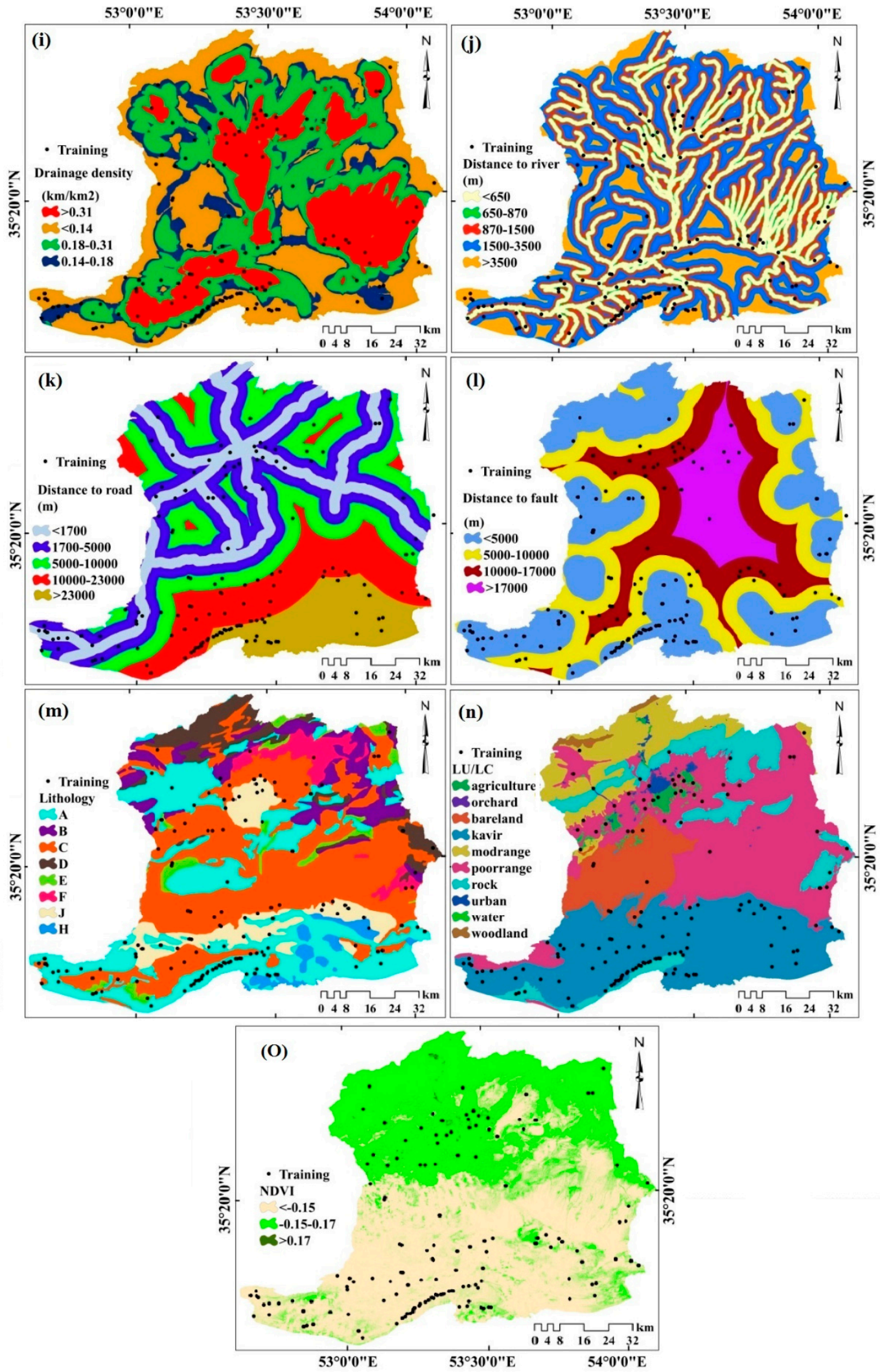

Figure 4. Gully erosion conditioning factors. (a) Elevation, (b) slope, (c) aspect, (d) plan curvature, (e) stream power index (SPI), (f) topographical wetness index (TWI), (g) rainfall, (h) soil type) (i) drainage density, (j) distance to river, (k) distance to road, (l) distance to fault, (m) lithology, (n) land use/land cover, and (o) normalized difference vegetation index (NDVI). 
To prepare the annual rainfall data, the rainfall statistics of Gandab, Ghahvehkhaneh-Bahar, Mahdi-Shahr, Dar-Jazin, Istegah-Pajohesh-Semnan, Kheir-Abad- Semnan, Attary, Shahmirzad, Abkhorieh-Semnan, Semnan, Chah-Kashani, Lahoord, and Sorkheh climate stations for a 30-year period (1986 to 2016) were used, and a statistical interpolation method was applied to prepare the final rainfall map. Univariate kriging was applied because it includes the simple kriging, ordinary kriging, universal kriging, and block kriging. In this study, ordinary kriging was selected to minimize the variance of error. Ordinary kriging assumes that the mean is locally constant based on the estimated point, which was adjusted to the requirements of our study area and variables.

The types of land use/land cover (LU/LC) and soil types were prepared following the information provided by the soil map of the Isfahan Agricultural and Natural Resources, Research and Education Center (http://esfahan.areeo.ac.ir/) at 1:100,000 scale, the geological map of the Geological Society of Iran (GSI) (http://www.gsi.ir/) at 1:100,000 scale, and the land use map from the Iranian Soil Conservation and Watershed Management Research Institute (https://www.scwmri.ac.ir) at 1:100,000 scale.

Finally, all layers were unified in the 12.5-meter pixel size (the same spatial resolution as the DEM) and the UTM Zone39N geographic coordinate system. An overview of the factors used for gully erosion susceptibility mapping is shown in Table 1.

Table 1. Overview of factors used for gully erosion susceptibility mapping.

\begin{tabular}{|c|c|c|c|c|}
\hline Factor & Source & Resolution & Classes & Method \\
\hline Elevation & PALSAR DEM & $12.5 \mathrm{~m}$ & $\begin{array}{c}\text { 1. }(<890 \mathrm{~m}), 2 .(890 \mathrm{~m}-935 \mathrm{~m}) \\
\text { 3. }(935 \mathrm{~m}-1100 \mathrm{~m}) \\
\text { 4. }(1100 \mathrm{~m}-1600 \mathrm{~m}), 5 .(>1600 \mathrm{~m})\end{array}$ & Natural break \\
\hline Slope & PALSAR DEM & $12.5 \mathrm{~m}$ & $\begin{array}{c}\text { 1. }\left(<5^{\circ}\right), 2 \cdot\left(5^{\circ}-10^{\circ}\right), \text { 3. }\left(10^{\circ}-20^{\circ}\right) \\
\text { 4. }\left(20^{\circ}-30^{\circ}\right), \text { 5. }\left(>30^{\circ}\right)\end{array}$ & Natural break \\
\hline Aspect & PALSAR DEM & $12.5 \mathrm{~m}$ & $\begin{array}{l}\text { 1. Flat }\left(-1^{\circ}\right), 2 \text {. North }\left(337.5-360^{\circ} \text {, }\right. \\
\text { 0-22.5 }), 3 \text {. Northeast }\left(22.5-67.5^{\circ}\right) \text {, } \\
\text { 4. East }\left(67.5-112.5^{\circ}\right), 5 . \text { Southeast } \\
\left(112.5-157.5^{\circ}\right), 6 . \text { South }\left(157.5-202.5^{\circ}\right) \text {, } \\
\text { 7. Southwest }\left(202.5-247.5^{\circ}\right), 8 \text {. West } \\
\left(247.4-292.5^{\circ}\right), \text { and } 9 . \text { Northwest } \\
\left(292.5-337.5^{\circ}\right)\end{array}$ & Equal interval \\
\hline Plan curvature & PALSAR DEM & $12.5 \mathrm{~m}$ & $\begin{array}{l}\text { 1. Concave }(<-0.05), 2 \text {. Flat } \\
(-0.05-0.05), 3 \text {. Convex }(>0.5)\end{array}$ & Natural break \\
\hline SPI & PALSAR DEM & $12.5 \mathrm{~m}$ & $\begin{array}{c}\text { 1. }(<9.2), 2 .(9.2-11.03), 3 .(11.03-3.02) \\
\text { 4. }(13.02-15.89) .5 .(>15.89)\end{array}$ & Natural break \\
\hline TWI & PALSAR DEM & $12.5 \mathrm{~m}$ & $\begin{array}{l}\text { 1. }(<4.41), 2 .(4.41-6.84) \\
\text { 3. }(6.84-10.44)(>10.44)\end{array}$ & Natural break \\
\hline Rainfall & $\begin{array}{l}\text { weather } \\
\text { stations }\end{array}$ & $\cdots$ & $\begin{array}{l}\text { 1. }(<-1.06), 2 .(-1.06-0.87) \\
\text { 3. }(0.87-3.99), 4 .(>3.99)\end{array}$ & Natural break \\
\hline Soil type & Soil map & $1: 100,000$ & $\begin{array}{l}\text { 1. }(<125 \mathrm{~mm}), 2 .(125-215 \mathrm{~mm}) \text {, } \\
\text { 3. }(215-350 \mathrm{~mm}), 4 .(>350 \mathrm{~mm})\end{array}$ & Natural break \\
\hline Drainage density & PALSAR DEM & $12.5 \mathrm{~m}$ & $\begin{array}{c}\text { 1. }\left(<0.14 \mathrm{~km} / \mathrm{km}^{2}\right), 2 .(0.14-0.18 \\
\left.\mathrm{km} / \mathrm{km}^{2}\right), 3 .\left(0.18-0.31 \mathrm{~km} / \mathrm{km}^{2}\right) \\
4\left(>0.31 \mathrm{~km} / \mathrm{km}^{2}\right)\end{array}$ & Natural break \\
\hline Distance to river & PALSAR DEM & $12.5 \mathrm{~m}$ & $\begin{array}{c}\text { 1. }(<650 \mathrm{~m}), 2 .(650 \mathrm{~m}-870 \mathrm{~m}) \\
\text { 3. }(870 \mathrm{~m}-1500 \mathrm{~m}) \\
\text { 4. }(1500 \mathrm{~m}-3500 \mathrm{~m}), 5 .(>3500 \mathrm{~m})\end{array}$ & Natural break \\
\hline Distance to road & $\begin{array}{l}\text { Topography } \\
\text { map }\end{array}$ & $1: 50,000$ & $\begin{array}{c}\text { 1. }(<1700 \mathrm{~m}), 2 .(1700-5000 \mathrm{~m}) \\
\text { 3. }(5000-10,000 \mathrm{~m}) \\
\text { 4. }(10,000-23,000 \mathrm{~m}), 5 .(>23,000)\end{array}$ & Natural break \\
\hline Distance to fault & Geology map & $1: 100,000$ & $\begin{array}{l}\text { 1. }(<5000 \mathrm{~m}), 2(5000-10,000 \mathrm{~m}) \text {, } \\
\text { 3. }(10,000-17,000), 4 .(>17,000)\end{array}$ & Natural break \\
\hline Lithology & Geology map & $1: 100,000$ & $\begin{array}{c}\text { 1. (A), 2.(B), 3. (C), 4. (D), 5. (E), 6. (F), } \\
\text { 7. (J), 8. (H). }\end{array}$ & Lithological units \\
\hline $\mathrm{LU} / \mathrm{LC}$ & Landuse map & $1: 100,000$ & $\begin{array}{c}\text { 1. (Agriculture), 2. (Orchard), } \\
\text { 3. (Barelans), 4. (Kavir), } 5 . \\
\text { (Modrange), 6. (Poorrange), 7. (Rock), } \\
\text { 8. (Urban), 9. (Water), 10. (Woodland). }\end{array}$ & $\begin{array}{l}\text { Supervised } \\
\text { classification }\end{array}$ \\
\hline NDVI & Landsat 8 & $30 \mathrm{~m}$ & 1. $(<-0.15), 2 .(-0.15-0.17), 3(>0.17)$ & Natural break \\
\hline
\end{tabular}




\subsection{Multicollinearity Test (MT)}

The collinearity is a model that indicates an independent variable is the linear function of other independent variables. If the collinearity in a regression equation obtains an elevated value, it indicates a strong correlation among the independent variables, which reduces the accuracy of the model [55]. In this research, the two indicators of TOL and VIF were used to study the collinearity among independent variables. If the value of TOL is $\leq 1$ and that of VIF is $\geq 10$, then the existence of collinearity among the independent factors is confirmed.

\subsection{Models Used}

\subsubsection{Index of Entropy (IoE)}

Entropy is one of the management approaches used to deal with irregularities and uncertainties in a system [56]. In order to prioritize the effective factors in the occurrence of the gully and to prepare its susceptibility map using the method mentioned above, the following equations have been used [57]:

$$
\begin{gathered}
\left(P_{i j}\right)=\frac{P_{i j}}{\sum_{j=1}^{S j} P_{i j}} \\
H_{j}=-\sum_{i=1}^{S j}\left(P_{i j}\right) \log _{2}\left(P_{i j}\right), \quad j=1, \ldots, n \\
H_{j} \max =\log _{2} S_{j} \quad S_{j}-\text { number of classes } \\
I_{j}=\frac{H_{j \max -H_{J}}}{H_{j} \max }, I=(0,1), \quad j=1, \ldots, n \\
W_{J}=I_{j} P_{i j}
\end{gathered}
$$

where (Pij) is the probability density, $H j$ and $H j_{\text {max }}$ represent the entropy values and maximum entropy, respectively, $I j$ is the information value, $S j$ is the number of categories, and $W j$ represents the resultant weight value for each factor. The range of $w j$ is between 0 and 1 . After calculating the final weight of each factor and their classes, these values were added in each related map and then weighted. Finally, they were added up, and the final gully erosion susceptibility map was prepared using Equation (9) and the weighted sum tool in ArcGIS [58].

$$
\operatorname{GESM}=\sum_{\mathrm{I}=1}^{\mathrm{n}}\left(\mathrm{W}_{\mathrm{J}} \times \mathrm{P}_{\mathrm{j}}\right)
$$

where $W j$ and $P j$ are the final weight and the probability density for the $j t h$ feature.

\subsubsection{VIKOR}

MCDM is a common decision methodology in environmental science because it can increase the accuracy of decisions by rendering the process in a highly rational and efficient manner [59-66]. The VIKOR model is based on the adaptive planning of multi-criteria decision-making problems. The emphasis is on ranking and choosing from a set of alternatives and identifying an agreeable solution to the problem with conflicting criteria [67]. In a situation where the decision-maker is unable to identify and express the advantages of an issue at the time of its initiation and design, this method can be considered as an effective and powerful tool for decision-making. This approach focuses on the selection of a set of alternatives and sets up compromise responses for an issue with opposite criteria. Thus, it can help decision-makers to reach a final decision. The main difference between this model and other models, such as AHP, is that in these models there are no paired comparisons between criteria 
and alternatives, and each alternative is independently measured and evaluated by a criterion [68]. This model consists of five steps, namely:

1. Creating the decision matrix according to the number of criteria and alternatives

$$
\mathrm{A}_{\mathrm{ij}}=\left[\begin{array}{cccc}
\mathrm{a}_{11} & \mathrm{a}_{12} & \ldots & \mathrm{a}_{1 \mathrm{n}} \\
\mathrm{a}_{21} & \mathrm{a}_{22} & \ldots & \mathrm{a}_{2 \mathrm{n}} \\
\cdot & \cdot & & \cdot \\
\cdot & \cdot & & \cdot \\
\mathrm{a}_{\mathrm{m} 1} & \mathrm{a}_{\mathrm{m} 2} & \ldots & \mathrm{a}_{\mathrm{mn}}
\end{array}\right] .
$$

2. Standardizing the decision matrix using Equation (10):

$$
r_{i j}=\frac{a_{i j}}{\sqrt{\sum_{i=1}^{m} a_{i j}^{2}}} .
$$

3. Determining the weight of each criterion using expert knowledge

$$
\mathrm{W}_{\mathrm{i}}=\frac{\sum_{\mathrm{i}=1}^{\mathrm{n}} \mathrm{r}_{\mathrm{ij}}}{\mathrm{n}} .
$$

4. Determining the best and worst of the values available for each criterion (Equations (12) and (13))

$$
\begin{aligned}
& \mathrm{f}_{\mathrm{i}}^{+}=\max _{\mathrm{i}_{\mathrm{f}_{\mathrm{ij}}}} \\
& \mathrm{f}_{\mathrm{i}}^{-}=\min _{\mathrm{i}_{\mathrm{ij}}} .
\end{aligned}
$$

5. Calculating the utility and incompatibility indexes using Equations (14) and (15), respectively:

$$
\begin{gathered}
\mathrm{S}_{\mathrm{i}}=\mathrm{L}_{1, \mathrm{i}}=\frac{\sum_{\mathrm{i}=1}^{\mathrm{n}} \mathrm{W}_{\mathrm{j}}\left(\mathrm{f}_{\mathrm{i}}^{+}-\mathrm{f}_{\mathrm{ij}}\right)}{\left(\mathrm{f}_{\mathrm{i}}^{+}-\mathrm{f}_{\mathrm{i}}^{-}\right)} \\
\mathrm{R}_{\mathrm{i}}=\mathrm{L}_{\infty, \mathrm{i}}=\max \left[\sum_{\mathrm{i}=1}^{\mathrm{n}} \mathrm{W}_{\mathrm{j}}\left(\mathrm{f}_{\mathrm{i}}^{+}-\mathrm{f}_{\mathrm{ij}}\right) /\left(\mathrm{f}_{\mathrm{i}}^{+}-\mathrm{f}_{\mathrm{i}}^{-}\right)\right] .
\end{gathered}
$$

6. Calculating the VIKOR index $\left(\mathrm{Q}_{\mathrm{i}}\right.$ value) using Equation (16):

$$
\mathrm{Q}_{\mathrm{i}}=\mathrm{V} \times \frac{\left(\mathrm{S}_{\mathrm{i}}-\mathrm{S}^{*}\right)}{\left(\mathrm{S}^{-}-\mathrm{S}^{*}\right)}+(1-\mathrm{V}) \times \frac{\left(\mathrm{R}_{\mathrm{i}}-\mathrm{R}^{*}\right)}{\left(\mathrm{R}^{-}-\mathrm{R}^{*}\right)} .
$$

where $\mathrm{V}$ is a constant (0.5), $S^{*}$ is $\min S S^{-}{ }_{i}$, is $\max S_{\mathrm{i}}, R^{*}$ is $\min R_{i}$, and $R^{*}$ is $\max R_{i}$. Values of $Q_{i}$ can vary between 0 and 1 . The alternatives with a score of 1 are the best, and those with a score of 0 are the worst [68].

\subsection{Model Validation}

The verification of the results is a key step in GESM and gully erosion susceptibility mapping [30]. The area under the receiver operating characteristic (AUROC) curve is an efficient and accurate method for verifying GESMs [32,51]. In the current research, the AUROC curve was used to evaluate the efficiency of each model in preparing the gully erosion sensitivity map [52]. This curve is an effective method for assessing the quality of models and shows the percentage of the model's prediction [69]. In the AUROC curve approach, the number of pixels that are correctly predicted by the model is plotted against the number of pixels that are incorrectly predicted. The AUROC is usually between 0.5 and 1 , with values closer to 1 indicating a better performance of the method [70]. AUROC values can be classified as follows: $0.5-0.6$, poor; $>0.6-0.7$, average; $>0.7-0.8$, good; $>0.8-0.9$, very good; and $>0.9-1$, excellent [71]. 


\section{Results}

\subsection{Multicollinearity Test (MT)}

Our results show (Table 2) that of the 19 independent variables, the four variables of convergence index $(\mathrm{TOL}=0.07$ and VIF $=11.26)$, total curvature $(\mathrm{TOL}=0.06$ and VIF $=14.98), \mathrm{LS}(\mathrm{TOL}=0.08$ and $\mathrm{VIF}=11.23)$, and profile curvature $(\mathrm{TOL}=0.01$ and $\mathrm{VIF}=17.60)$ have collinearity and, therefore, cannot be used for modeling.

Table 2. Multicollinearity test among conditioning factors.

\begin{tabular}{|c|c|c|}
\hline \multirow{2}{*}{ Factors } & \multicolumn{2}{|c|}{ Collinearity Statistics } \\
\hline & Tolerance & VIF \\
\hline (Constant) & - & - \\
\hline Aspect & 0.890 & 1.124 \\
\hline Convergence & 0.0791 & 11.264 \\
\hline Total curvature & 0.067 & 14.980 \\
\hline Elevation & 0.106 & 4.012 \\
\hline Drainage density & 0.481 & 2.080 \\
\hline Dis to fault & 0.629 & 1.590 \\
\hline Dis to river & 0.549 & 1.822 \\
\hline Dis to road & 0.620 & 1.613 \\
\hline Profile curvature & 0.0132 & 17.604 \\
\hline Plan curvature & 0.179 & 4.598 \\
\hline NDVI & 0.350 & 2.860 \\
\hline LS & 0.0808 & 11.238 \\
\hline TWI & 0.671 & 1.490 \\
\hline SPI & 0.721 & 1.386 \\
\hline Slope & 0.467 & 2.141 \\
\hline Rainfall & 0.331 & 3.020 \\
\hline LU & 0.564 & 1.775 \\
\hline Soil type & 0.283 & 3.535 \\
\hline Lithology & 0.867 & 1.153 \\
\hline
\end{tabular}

\subsection{Applying the Index of Entropy (IoE) Model}

The results of our analysis regarding the importance of the GRCFs using the IoE method revealed that the factors of soil type (1.8), LU/LC (1.3), and SPI (0.53) played the most important roles in the development of gullies in the study area. In contrast, the factors of distance to fault (0.001), aspect (0.02), and distance to road (0.02) were shown to be of least importance.

The spatial relationship between the GRCFs and the existing gullies in the study area are shown in Table 3. The results of the elevation factor analysis using the IoE method revealed that areas with low elevation are more sensitive to gully formation than the highlands. As such, the classes of $<890 \mathrm{~m}(\mathrm{IoE}=1.24)$ and 890-935 (IoE = 1.42) have the highest score. These results are in line with Arabameri et al. [17]. In terms of the slope, areas with a slope between $5^{\circ}$ and $10^{\circ}$ were more prone to gully erosion ( $\mathrm{IoE}=1.56$ ) than other areas, and, in contrast, slopes steeper than $20^{\circ}$ did not affect gully erosion. This is possibly because the accumulation of surface runoff and human activities were higher on the gently inclined areas [72]. With regard to the aspect factor, east aspects with IoE $=1.57$ were shown to have the most significant impact on gully occurrence. This was mainly due to lower vegetation cover density in the east-facing areas compared with other aspects. The findings are in agreement with those of Arabameri et al. [43]. In terms of plan curvature, concave $(\mathrm{IoE}=1.65)$ and flat $(\mathrm{IoE}=0.98)$ areas had the highest impact on gully occurrence compared to the convex $(\mathrm{IoE}=0.92)$ areas. The findings are in agreement with those of Arabameri et al. [43] and Rahmati et al. [72]. In the case of SPI and TWI, the classes of $<9.2$ and $>10.44$ with $\mathrm{IoE}=1.26$ and 3.78, respectively, were shown to have the most significant effect on gully occurrence. Results indicated that areas with low values of SPI and high value of TWI have a higher susceptibility to gully erosion. In areas with high values of 
TWI, the flow velocity, which is related to energy level of surface runoff, exceeds the soil shear stress and gully development [72].

The results related to rainfall indicated that the class of $125-215 \mathrm{~mm}$ with $\mathrm{IoE}=1.18$ and $>0.350$ with IoE $=0.17$ had the highest and the lowest effect on gully occurrence, respectively. In the study area, vegetation cover is sparse in areas with lower rainfall, but mountainous areas with higher rainfall have rocky outcrops and are not prone to gully erosion. These results are in line with Arabameri et al. [73]. Based on soil types, Aridisols $(\mathrm{IoE}=4.10)$ showed a strong dependency on the development of gullies in the study area. These soils are characterized by the presence of gypsum and evaporative soluble salts, which are highly sensitive to erosion [74,75].

In the case of the drainage density factor, the class of $0.14-0.18 \mathrm{~km} / \mathrm{km}^{2}$ with $\mathrm{IoE}=1.111$ showed a strong correlation with gully occurrence in this study area. A high drainage density causes a larger surface runoff ratio and areas with a high drainage density have a high susceptibility to gully erosion [43]. It is important to highlight the importance of the results related to the distance to rivers, faults, and roads. Several authors confirmed that the roads are one of the main causes of rill and gully development because of the destabilization of the hillslope and the elimination of the vegetation cover $[26,76,77]$. Our results indicated that the classes of $<650 \mathrm{~m},<5000 \mathrm{~m}$, and $>23,000 \mathrm{~m}$ with $\mathrm{IoE}=1.64,1.39$, and 1.46 , respectively, have the most impact on gully occurrence. These results are in agreement with Conoscenti et al. and Maliho et al. [28,33]. In the case of the lithology type, volcanic rocks ( $\mathrm{IoE}=1.73$ ) and clay accumulations (1.6) showed a higher susceptibility to gully occurrence than other lithology units. During the dry and wet seasons, areas with high clay contents are subject to cracks in the ground and piping processes can develop [78,79]. Also, agricultural areas are prone to an increase in connectivity processes, which can increase runoff peaks and sediment transport [80]. According to the LU/LC factor, Kavir areas ( $\mathrm{IoE}=1.63$ ) that cover the evaporation deposits such as gypsum and salt have a strong correlation with the location of gullies in the study area. The findings are in agreement with those of Arabameri et al. [43].

The results of the NDVI factor showed that vegetation plays a significant role in soil conservation against gully erosion, and that with increasing vegetation cover the sensitivity of the areas to this erosion decreases and that areas with the lowest vegetation cover have the highest susceptibility to gully erosion. The findings are in agreement with those of Arabameri et al. [43].

After determining the weights of factors and spatial relationships of GRCFs and gully locations, Equation (17) is used for obtaining the GESM.

$$
\begin{gathered}
\text { GESM }_{\mathrm{IoE}}=\left(\text { elevation }_{\mathrm{IoE}} \times 0.05\right)+\left(\text { slope }_{\mathrm{IoE}} \times 0.24\right)+\left(\text { aspect }_{\mathrm{IoE}} \times 0.02\right)+ \\
\left(\text { plan curvature }_{\mathrm{IoE}} \times 0.41\right)+\left(\mathrm{SPI}_{\mathrm{IoE}} \times 0.53\right)+\left(\mathrm{TWI}_{\mathrm{IoE}} \times 0.41\right)+ \\
\left(\text { Rainfall }_{\mathrm{IoE}} \times 0.11\right)+\left(\text { dis to stream }_{\mathrm{IoE}} \times 0.049\right)+\left(\text { dis to road }_{\mathrm{IoE}} \times 0.02\right)+ \\
\left(\text { dis to fault }_{\mathrm{IOE}} \times 0.001\right)+\left(\text { soil type }_{\mathrm{IoE}} \times 1.8\right)+\left(\mathrm{LU} / \mathrm{LC}_{\mathrm{IoE}} \times 1.3\right)+ \\
\left(\mathrm{NDVI}_{\mathrm{IoE}} \times 0.24\right)+\left(\text { lithology }_{\mathrm{IoE}} \times 0.048\right)+\left(\text { Drainage density }_{\mathrm{IoE}} \times 0.03\right)
\end{gathered}
$$

Values of the resulting GESM using the IoE model vary between 0.303 and 6.30. The resulting map using the natural break method is divided into five classes, namely very low (0.303-1.65), low (1.65-3.04), moderate (3.04-4.39), high (4.39-5.45), and very high (5.45-6.30) (Figure 5a). Based on results (Figure 6), $25.51 \%, 21.18 \%, 19.94 \%, 17.88 \%$, and $15.94 \%$ of the study area is located in very low to very high susceptibility classes, respectively. 
Table 3. Relationship between gully erosion and gully conditioning factors using the index of entropy.

\begin{tabular}{|c|c|c|c|c|c|c|c|}
\hline \multirow{2}{*}{ Factor } & \multirow{2}{*}{ Class } & \multicolumn{2}{|c|}{ Domain Pixels } & \multicolumn{2}{|c|}{ GULLY PIXELS } & \multirow{2}{*}{ Pij } & \multirow{2}{*}{$\mathbf{W j}$} \\
\hline & & No & $\%$ & No & $\%$ & & \\
\hline \multirow{5}{*}{ 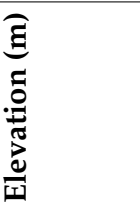 } & $<890$ & $2,879,578$ & 29.89 & 60 & 37.04 & 1.24 & \multirow{5}{*}{0.05} \\
\hline & $890-935$ & 710,494 & 7.37 & 17 & 10.49 & 1.42 & \\
\hline & 935-1100 & $2,013,677$ & 20.90 & 37 & 22.84 & 1.09 & \\
\hline & $1100-1600$ & $2,313,076$ & 24.01 & 39 & 24.07 & 1.00 & \\
\hline & $>1600$ & $1,717,478$ & 17.83 & 9 & 5.56 & 0.31 & \\
\hline \multirow{5}{*}{$\begin{array}{l}\sigma \\
\text { o } \\
\frac{0}{0}\end{array}$} & $<5$ & $6,899,986$ & 71.62 & 116 & 71.60 & 1.00 & \multirow{5}{*}{0.24} \\
\hline & $5-10$ & $1,070,376$ & 11.11 & 28 & 17.28 & 1.56 & \\
\hline & $10-20$ & 924,930 & 9.60 & 18 & 11.11 & 1.16 & \\
\hline & $20-30$ & 481,844 & 5.00 & 0 & 0.00 & 0.00 & \\
\hline & $>30$ & 257,167 & 2.67 & 0 & 0.00 & 0.00 & \\
\hline \multirow{9}{*}{$\begin{array}{l}\frac{\tilde{U}^{\prime}}{4} \\
\frac{0}{4}\end{array}$} & $\mathrm{~F}$ & 566,040 & 5.88 & 4 & 2.47 & 0.42 & \multirow{9}{*}{0.02} \\
\hline & $\mathrm{N}$ & 961,571 & 9.99 & 18 & 11.11 & 1.11 & \\
\hline & $\mathrm{NE}$ & 710,471 & 7.38 & 17 & 10.49 & 1.42 & \\
\hline & $\mathrm{E}$ & 872,929 & 9.07 & 23 & 14.20 & 1.57 & \\
\hline & SE & $1,383,590$ & 14.38 & 31 & 19.14 & 1.33 & \\
\hline & $S$ & $1,791,970$ & 18.62 & 23 & 14.20 & 0.76 & \\
\hline & SW & $1,428,212$ & 14.84 & 18 & 11.11 & 0.75 & \\
\hline & $\mathrm{W}$ & 994,513 & 10.33 & 11 & 6.79 & 0.66 & \\
\hline & NW & 915,376 & 9.51 & 17 & 10.49 & 1.10 & \\
\hline \multirow{3}{*}{ 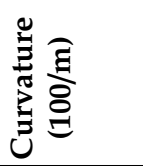 } & concave & 325,238 & 3.38 & 9 & 5.56 & 1.65 & \multirow{3}{*}{0.41} \\
\hline & flat & $8,726,972$ & 90.58 & 144 & 88.89 & 0.98 & \\
\hline & convex & 582,093 & 6.04 & 9 & 5.56 & 0.92 & \\
\hline \multirow{5}{*}{ 氞 } & $<9.2$ & $3,016,197$ & 31.36 & 64 & 39.51 & 1.26 & \multirow{5}{*}{0.53} \\
\hline & $9.2-11.03$ & $2,592,536$ & 26.95 & 25 & 15.43 & 0.57 & \\
\hline & $11.03-13.02$ & $2,452,601$ & 25.50 & 26 & 16.05 & 0.63 & \\
\hline & $13.02-15.89$ & $1,213,412$ & 12.61 & 14 & 8.64 & 0.69 & \\
\hline & $>15.89$ & 344,608 & 3.58 & 33 & 20.37 & 0.69 & \\
\hline \multirow{4}{*}{$\sum_{i}^{\mathfrak{g}}$} & $<4.41$ & $2,642,289$ & 27.47 & 40 & 24.69 & 0.90 & \multirow{4}{*}{0.41} \\
\hline & $4.41-6.84$ & $4,350,350$ & 45.22 & 60 & 37.04 & 0.82 & \\
\hline & $6.84-10.44$ & $2,077,423$ & 21.60 & 27 & 16.67 & 0.77 & \\
\hline & $>10.44$ & 549,292 & 5.71 & 35 & 21.60 & 3.78 & \\
\hline \multirow{4}{*}{ 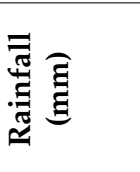 } & $<125$ & $6,422,553$ & 66.64 & 118 & 72.84 & 1.09 & \multirow{4}{*}{0.11} \\
\hline & $125-215$ & $1,961,321$ & 20.35 & 39 & 24.07 & 1.18 & \\
\hline & $215-350$ & 894,195 & 9.28 & 4 & 2.47 & 0.27 & \\
\hline & $>350$ & 358,963 & 3.72 & 1 & 0.62 & 0.17 & \\
\hline \multirow{6}{*}{$\frac{0}{2}$} & $\begin{array}{c}\text { Rock } \\
\text { Outcrops/Entisols }\end{array}$ & $2,878,863$ & 29.87 & 27 & 16.67 & 0.56 & \multirow{5}{*}{1.8} \\
\hline & Entisols/Aridisols & $1,495,535$ & 15.52 & 18 & 11.11 & 0.72 & \\
\hline & Inceptisols & 63,063 & 0.65 & 17 & 10.49 & 16 & \\
\hline & Aridisols & 842,361 & 8.74 & 58 & 35.80 & 4.10 & \\
\hline & Bad Lands & $2,307,771$ & 23.95 & 42 & 25.93 & 1.08 & \\
\hline & Salt Flats & $2,049,443$ & 21.27 & 0 & 0.00 & 0.00 & \\
\hline$\because \widetilde{T}$ & $<0.14$ & $2,847,934$ & 29.64 & 51 & 31.48 & 1.06 & \\
\hline 䨔 & $0.14-0.18$ & $1,233,569$ & 12.84 & 23 & 14.20 & 1.11 & 0.03 \\
\hline छ छ & $0.18-0.31$ & $3,165,207$ & 32.95 & 44 & 27.16 & 0.82 & \\
\hline & $>0.31$ & $2,360,559$ & 24.57 & 44 & 27.16 & 1.11 & \\
\hline
\end{tabular}


Table 3. Cont

\begin{tabular}{|c|c|c|c|c|c|c|c|}
\hline \multirow{2}{*}{ Factor } & \multirow{2}{*}{ Class } & \multicolumn{2}{|c|}{ Domain Pixels } & \multicolumn{2}{|c|}{ GULLY PIXELS } & \multirow{2}{*}{$P i j$} & \multirow{2}{*}{$\mathbf{W j}$} \\
\hline & & No & $\%$ & No & $\%$ & & \\
\hline \multirow{5}{*}{ 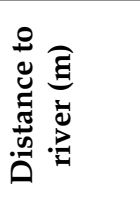 } & $<650$ & $2,715,295$ & 28.19 & 75 & 46.30 & 1.64 & \multirow{5}{*}{0.049} \\
\hline & $650-870$ & 793,728 & 8.24 & 12 & 7.41 & 0.90 & \\
\hline & $870-1500$ & $1,906,357$ & 19.79 & 23 & 14.20 & 0.72 & \\
\hline & $1500-3500$ & $3,202,074$ & 33.24 & 29 & 17.90 & 0.54 & \\
\hline & $>3500$ & $1,016,201$ & 10.55 & 23 & 14.20 & 1.35 & \\
\hline \multirow{4}{*}{ 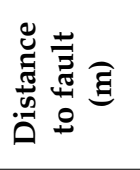 } & $<5000$ & $3,642,736$ & 37.90 & 85 & 52.80 & 1.39 & \multirow{4}{*}{0.001} \\
\hline & $5000-10,000$ & $2,778,443$ & 28.91 & 30 & 18.63 & 0.64 & \\
\hline & $10,000-17,000$ & $2,095,468$ & 21.80 & 34 & 21.12 & 0.97 & \\
\hline & $>17,000$ & $1,094,885$ & 11.39 & 12 & 7.45 & 0.65 & \\
\hline \multirow{5}{*}{ 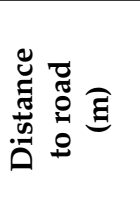 } & $<1700$ & $1,705,351$ & 17.74 & 30 & 18.52 & 1.04 & \multirow{5}{*}{0.02} \\
\hline & $1700-5000$ & $2,582,564$ & 26.86 & 36 & 22.22 & 0.83 & \\
\hline & $5000-10,000$ & $2,308,778$ & 24.02 & 28 & 17.28 & 0.72 & \\
\hline & $10,000-23,000$ & $1,840,552$ & 19.15 & 39 & 24.07 & 1.26 & \\
\hline & $>23,000$ & $1,176,036$ & 12.23 & 29 & 17.90 & 1.46 & \\
\hline \multirow{8}{*}{ 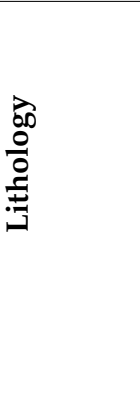 } & Marl, Gypsum & $2,738,777$ & 28.42 & 63 & 38.89 & 1.37 & \multirow{8}{*}{0.048} \\
\hline & $\begin{array}{c}\text { Conglomerate, } \\
\text { Sandstone, Shale, Tuff }\end{array}$ & 803,953 & 8.34 & 6 & 3.70 & 0.44 & \\
\hline & Terraces deposits & $3,718,139$ & 38.58 & 45 & 27.78 & 0.72 & \\
\hline & $\begin{array}{l}\text { Dolomite, Limestone, } \\
\text { Sandstone, Shale }\end{array}$ & 653,507 & 6.78 & 9 & 5.56 & 0.82 & \\
\hline & Fluvial conglomerate & 288,376 & 2.99 & 3 & 1.85 & 0.62 & \\
\hline & Volcanic rocks & 378,802 & 3.93 & 11 & 6.79 & 1.73 & \\
\hline & Clay & 817,583 & 8.48 & 22 & 13.58 & 1.60 & \\
\hline & Salt & 237,994 & 2.47 & 3 & 1.85 & 0.75 & \\
\hline \multirow{10}{*}{ 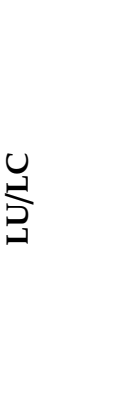 } & Agriculture & 175,440 & 1.83 & 4 & 2.47 & 1.35 & \multirow{10}{*}{1.3} \\
\hline & Orchard & 6315 & 0.07 & 0 & 1.23 & 0 & \\
\hline & Bareland & 896,113 & 9.33 & 9 & 5.56 & 0.60 & \\
\hline & Kavir & $3,025,781$ & 31.49 & 83 & 51.23 & 1.63 & \\
\hline & Modrange & 984,453 & 10.24 & 4 & 2.47 & 0.24 & \\
\hline & Poorrange & $3,230,325$ & 33.62 & 44 & 27.16 & 0.81 & \\
\hline & Rock & $1,145,924$ & 11.92 & 14 & 8.64 & 0.72 & \\
\hline & Urban & 81,661 & 0.85 & 0 & 1.23 & 0 & \\
\hline & Water & 185 & 0.00 & 0 & 0.00 & 0 & \\
\hline & Woodland & 63,487 & 0.66 & 0 & 0.00 & 0 & \\
\hline \multirow{3}{*}{2} & $<-0.15$ & $5,656,113$ & 58.77 & 100 & 61.73 & 1.05 & \multirow{3}{*}{0.24} \\
\hline & $-0.15-0.17$ & $3,953,406$ & 41.08 & 62 & 38.27 & 0.93 & \\
\hline & $>0.17$ & 14,906 & 0.15 & 0 & 0.00 & 0.00 & \\
\hline
\end{tabular}




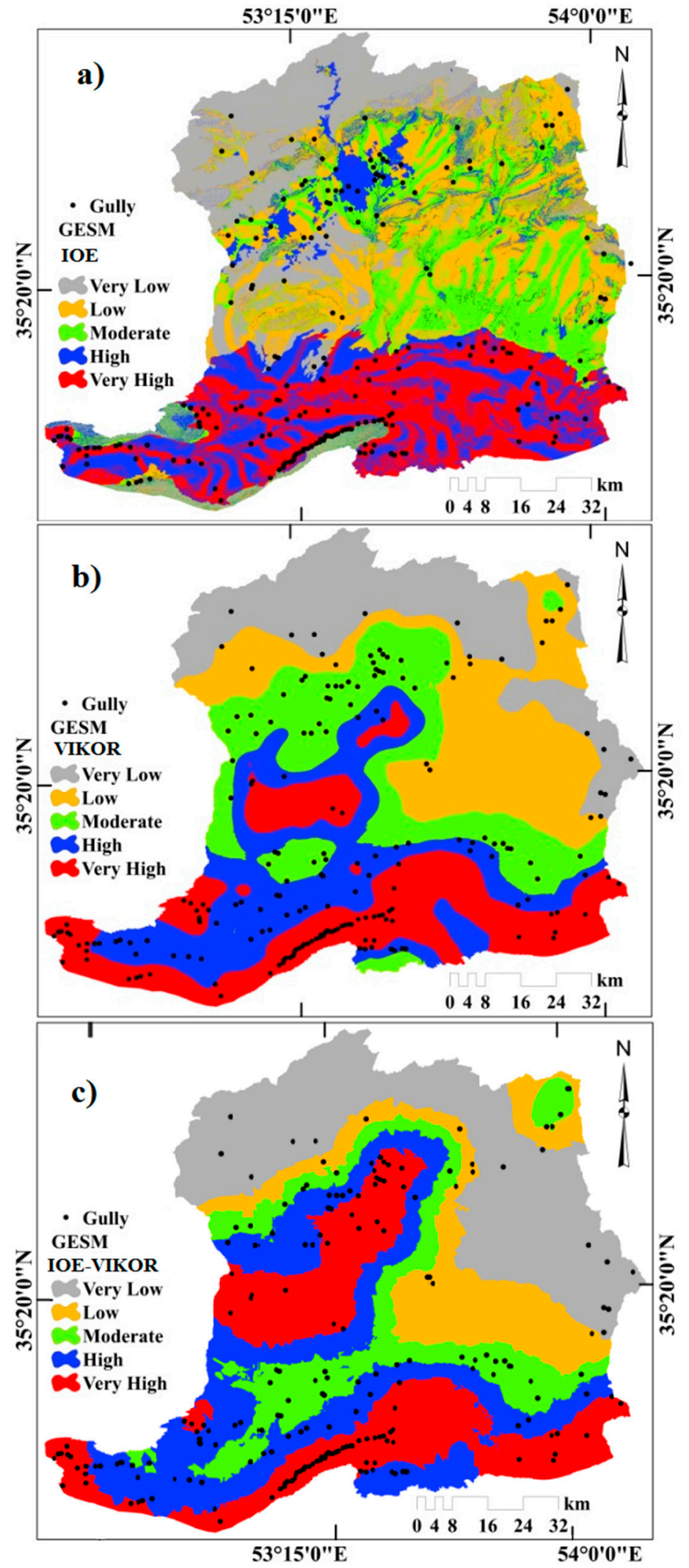

Figure 5. Gully erosion susceptibility mapping. (a) Index of entropy (IoE) model, (b) Vlse Kriterijumska Optimizacija I Kompromisno Resenje (VIKOR) model, (c) IoE-VIKOR integrated model. 


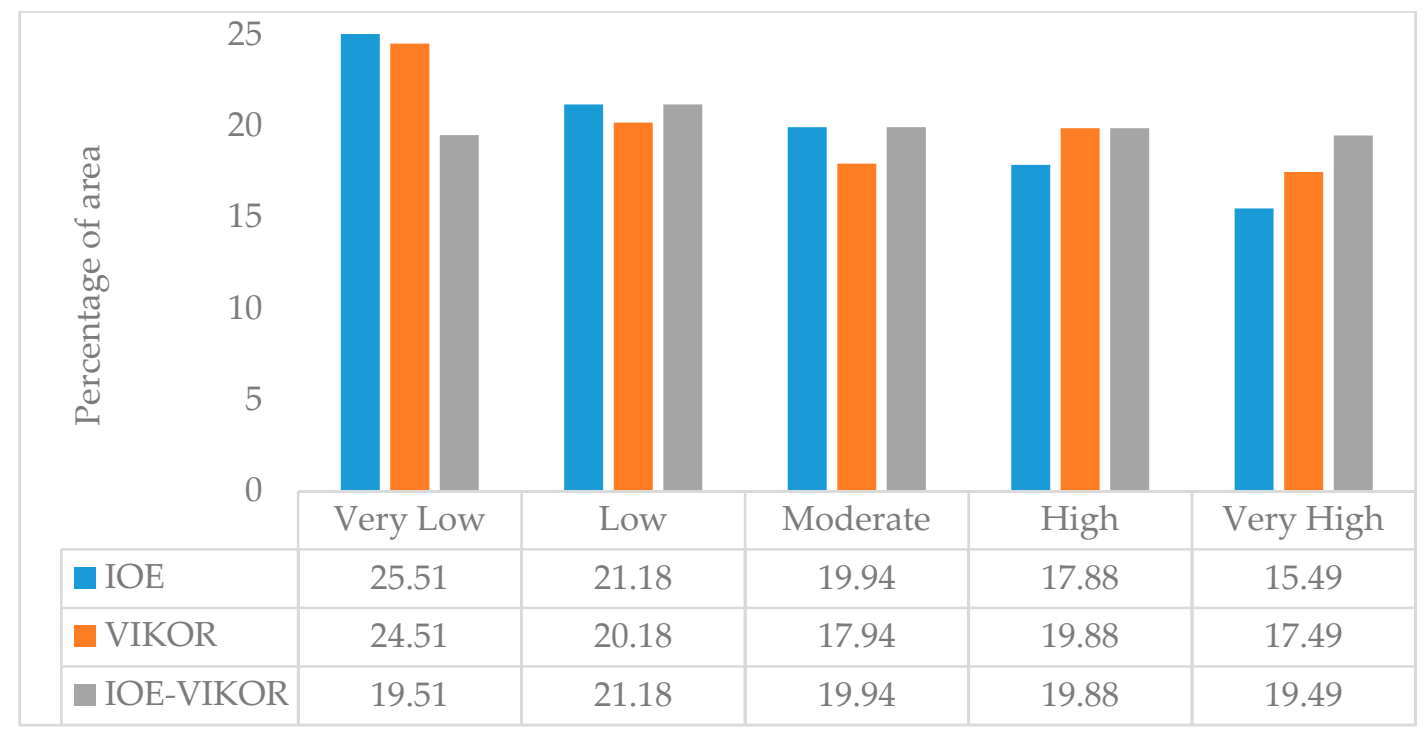

Figure 6. Percentage of each susceptibility class in different models.

\subsection{Applying the VIKOR Model}

Before applying the VIKOR model, we calculated the weight of the GRCFs using pairwise comparisons and expert knowledge. According to the results of the expert knowledge method (Figure 7), soil types (0.368), lithology (0.213), and elevation (0.097) had the biggest impact on gully erosion in this study area. In a second group of factors, we can also consider with lower influence rainfall (0.088), LU/LC (0.074), slope (0.48), distance to road (0.033), plan curvature (0.023), distance to river (0.018), distance to fault (0.008), drainage density (0.006), aspect (0.004), TWI (0.001), and SPI (0.0003).

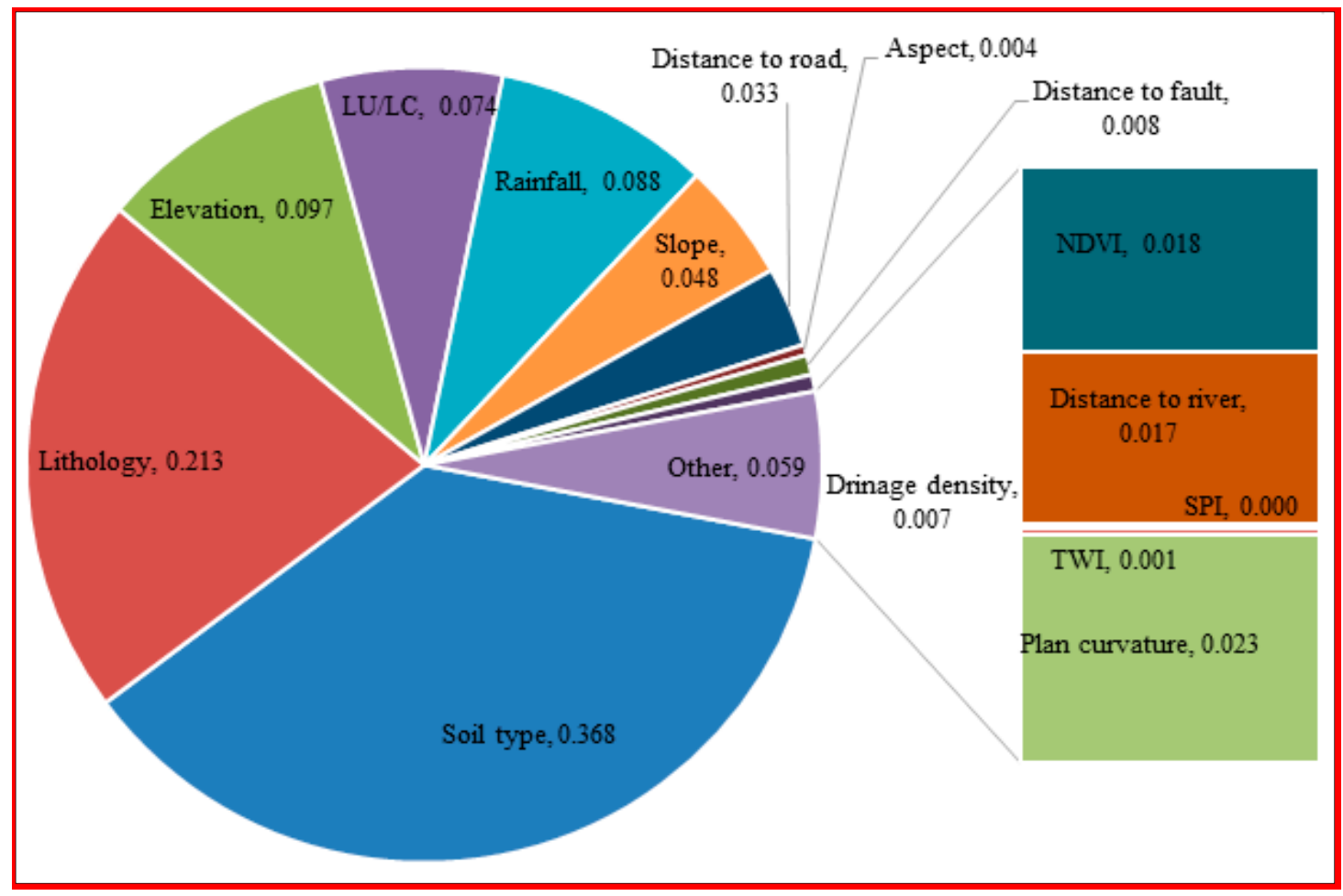

Figure 7. Weight of the criteria (gully erosion conditioning factors) using the analytic hierarchy process (AHP) model. 
The values obtained using the VIKOR model in each sample point are shown in Table 4 . The results obtained from the GESM using the VIKOR model ranged from 0.055 to 0.984 . These values were divided into five classes: $0.055-0.248$ (very low), 0.248-0.404 (low), 0.404-0.575 (moderate), 0.0575-0.752 (high), and 0.752-0.984 (very high) (Figure 5b). Based on the results (Figure 6), a total of $24.5 \%$ of the study area is located in the very low susceptibility class. Furthermore, $20.2 \%$ is situated in the low susceptibility and $17.9 \%$ in moderate susceptibility class, while $19.9 \%$ was in the high susceptibility and $17.5 \%$ in the very high susceptibility class.

Table 4. Values of the VIKOR and IoE-VIKOR models in each random point.

\begin{tabular}{ccccccc}
\hline \multirow{2}{*}{ pint } & \multicolumn{3}{c}{ VIKOR-IoE } & \multicolumn{3}{c}{ VIKOR } \\
& $\mathbf{S}$ & $\mathbf{R}$ & $\mathbf{Q}$ & $\mathbf{S}$ & $\mathbf{R}$ & $\mathbf{Q}$ \\
\hline 1 & 2.088 & 1.418 & 0.095 & 0.732 & 0.326 & 0.117 \\
2 & 0.108 & 0.022 & 0.989 & 0.065 & 0.015 & 0.983 \\
3 & 1.808 & 1.420 & 0.158 & 0.552 & 0.327 & 0.231 \\
4 & 1.295 & 1.021 & 0.401 & 0.399 & 0.235 & 0.459 \\
5 & 0.276 & 0.193 & 0.897 & 0.166 & 0.118 & 0.773 \\
6 & 0.412 & 0.193 & 0.866 & 0.238 & 0.118 & 0.727 \\
7 & 2.077 & 1.418 & 0.097 & 0.724 & 0.326 & 0.122 \\
8 & 1.791 & 1.420 & 0.162 & 0.540 & 0.327 & 0.239 \\
9 & 0.416 & 0.193 & 0.865 & 0.249 & 0.118 & 0.720 \\
10 & 1.648 & 1.110 & 0.293 & 0.588 & 0.255 & 0.309 \\
11 & 2.072 & 1.418 & 0.098 & 0.724 & 0.326 & 0.122 \\
12 & 0.134 & 0.073 & 0.967 & 0.091 & 0.037 & 0.935 \\
13 & 0.126 & 0.028 & 0.983 & 0.067 & 0.015 & 0.981 \\
14 & 0.090 & 0.033 & 0.990 & 0.065 & 0.020 & 0.976 \\
15 & 1.800 & 1.418 & 0.161 & 0.550 & 0.326 & 0.233 \\
16 & 1.480 & 1.110 & 0.331 & 0.455 & 0.255 & 0.394 \\
17 & 1.773 & 1.420 & 0.166 & 0.537 & 0.327 & 0.241 \\
18 & 1.836 & 1.420 & 0.152 & 0.573 & 0.327 & 0.218 \\
19 & 1.523 & 1.110 & 0.321 & 0.491 & 0.255 & 0.371 \\
20 & 0.103 & 0.025 & 0.989 & 0.060 & 0.017 & 0.984 \\
21 & 1.360 & 1.021 & 0.387 & 0.441 & 0.235 & 0.432 \\
22 & 1.380 & 1.021 & 0.382 & 0.442 & 0.235 & 0.431 \\
23 & 0.590 & 0.335 & 0.780 & 0.343 & 0.206 & 0.536 \\
24 & 0.231 & 0.134 & 0.926 & 0.120 & 0.068 & 0.873 \\
25 & 1.170 & 1.021 & 0.430 & 0.324 & 0.235 & 0.506 \\
26 & 0.423 & 0.193 & 0.863 & 0.243 & 0.118 & 0.723 \\
27 & 0.195 & 0.097 & 0.945 & 0.122 & 0.060 & 0.884 \\
28 & 0.437 & 0.338 & 0.814 & 0.276 & 0.208 & 0.576 \\
29 & 2.027 & 1.418 & 0.109 & 0.684 & 0.326 & 0.148 \\
30 & 1.125 & 1.021 & 0.440 & 0.299 & 0.235 & 0.522 \\
31 & 0.421 & 0.193 & 0.864 & 0.249 & 0.118 & 0.720 \\
32 & 1.478 & 1.110 & 0.332 & 0.475 & 0.255 & 0.381 \\
33 & 0.102 & 0.026 & 0.989 & 0.067 & 0.016 & 0.981 \\
34 & 1.792 & 1.418 & 0.162 & 0.538 & 0.326 & 0.241 \\
35 & 1.930 & 1.418 & 0.131 & 0.618 & 0.326 & 0.190 \\
36 & 1.798 & 1.420 & 0.160 & 0.541 & 0.327 & 0.238 \\
37 & 1.848 & 1.418 & 0.149 & 0.580 & 0.326 & 0.214 \\
\hline & & & & & &
\end{tabular}

\subsection{Integration of IoE and VIKOR Models and Validation}

The values obtained from the GESM ranged from 0.068 and 0.975 . These values were classified into five classes to range from very low to very high based on the natural break interval method (Figure 5c). According to our results (Figure 6), 19.5\%, 21\%, 19.9\%, 19.9\%, and 19.5\% of the study area had a very low, low, moderate, high, and very high susceptibility, respectively. Finally, the results of GESMs were validated using the IoE, VIKOR, and IoE-VIKOR integrated model with the AUROC curve (Figure 8). It was shown that the IoE model (AUROC $=0.941$ ) had a higher prediction accuracy 
than the other models, and that the combination of the IoE with VIKOR models (AUROC $=0.868$ ) increased the accuracy of the VIKOR MCDM model (AUROC $=0.857$ ). The IoE model obtained an AUROC $=0.868$ prediction accuracy, while the VIKOR model obtained an AUROC $=0.857$.

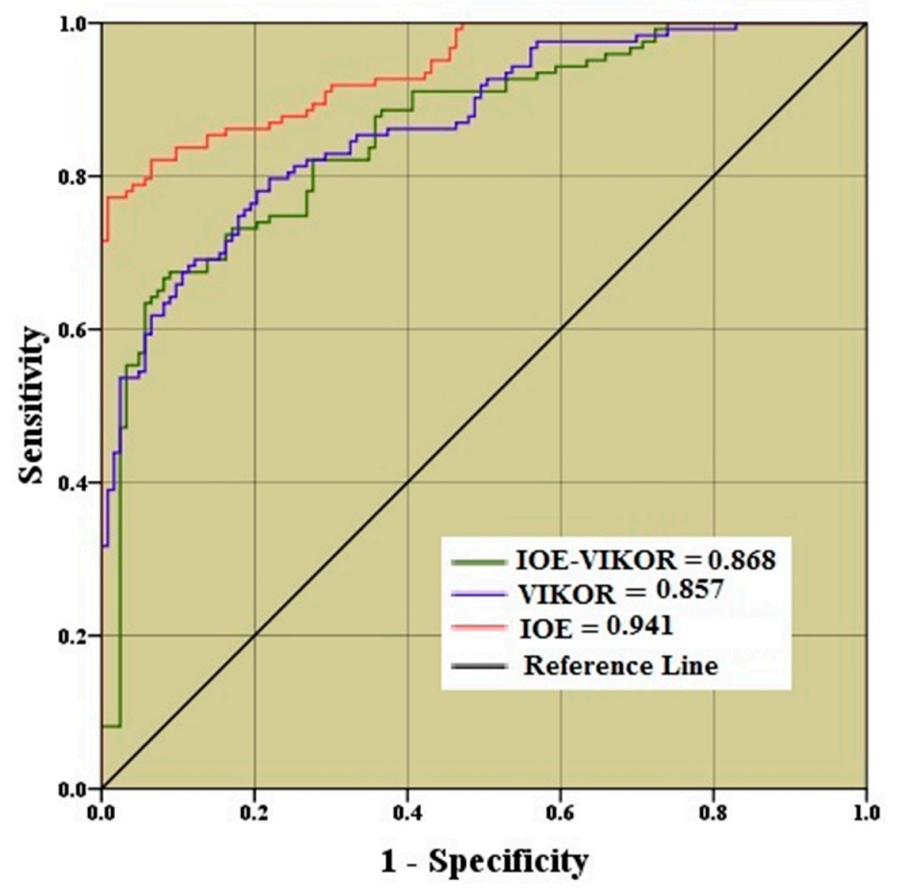

Figure 8. Validation of models.

\section{Discussion}

The evaluation of susceptibility to gully erosion is crucial for planning erosion control measures and mitigating the effects of this process. We demonstrated that the spatial distribution of gully erosion can be predicted by exploiting GIS analysis tools and establishing statistical relationships between gully occurrence and variability of physical variables related to topography, bedrock, soils, land cover, and rainfall. We used different modeling techniques, including statistical and data mining/machine learning, to achieve these results. In this research, a new scientific approach was developed to provide a gully erosion sensitivity map that does not require the location of gullies. This is very useful for areas that lack accurate data [81,82]. For this purpose, we confirmed that VIKOR MCDM models could be used and improved its efficiency and accuracy if the IoE bivariate model is integrated with it without comparing gullies data with each other.

The variables that we found to play a key role in our models, such as soil type, LU/LC, SPI, lithology, or elevation, are in line with other traditional and recent investigations conducted on gully erosion $[27,37,40]$. Zakerinejad and Maerker [27] used the maximum entropy model to investigate the sensitivity of the Maziyegan area of Fars province in Iran to gully erosion and demonstrated that many factors influence the occurrence and development of this type of erosion, including those also highlighted in our research, namely soil type, lithology, and LU/LC. Dube et al. [37] assessed gully erosion susceptibility mapping using the weight of evidence model in New Zealand and demonstrated that soil type, distance from streams, and LU/LC were the main factors affecting gully erosion. Rahmati et al. [40] compared the performance of seven state-of-the-art machine learning models, including SVM with four kernel types, BP-ANN, RF, and BRT to model the occurrence of gully erosion in the Kashkan-Poldokhtar Watershed, Iran, and stated that the drainage density, elevation, and distance to roads played a crucial role in gully occurrence. Reference [43] proposed a new model by combining the geographically weighted regression (GWR) technique with the certainty factor (CF) and random forest (RF) models to produce gully erosion zonation maps in the Mahabia watershed 
(Iran), and indicated that the distance to streams, distance to roads, and LU/LC factors were of primary importance in terms of gully occurrence. Our results also agree with other types of investigation carried out with field experiments where parent material, land use changes, and slope positions are key factors of soil erosion processes at smaller scales, such as hillslopes and pedons ones [41].

The validation of our results showed that IoE had a higher prediction accuracy than the VIKOR model and that the combination of IoE with VIKOE increased the prediction accuracy of the VIKOR model. These results were also confirmed by Zabihi et al. [32] and Arabameri et al. [41]. One of the main advantages of the IoE method is that this method can determine the importance of effective factors and analyze the spatial relationship between effective factors and gullies occurring in the study area [52]. The IoE model demonstrated how the most important factor could be estimated from the factors affecting the phenomenon (gully erosion) occurrence [83]. In other words, it can identify the variables that have the highest impact on the event of a phenomenon, which is important because, depending on the physiographic conditions of the area, there are usually several factors affecting gully erosion. Also, in determining the risk susceptibility using bivariate and probable statistical models, all effective factors showed the same weight, so if one factor has more impact, the effect will be ignored [84]. Therefore, the aforementioned theory as a management approach can have a significant role in the identification of effective factors and their impact on phenomena occurrence [17]. The results also confirmed that the combination of the IoE method with the VIKOR method increased the prediction accuracy of the VIKOR model. Thus, we stated that it is vital to check the effectiveness of the combination of different models rather than using single models adapted to each study area.

\section{Conclusions}

For gully erosion mapping, three different models (IoE, VIKOR, and IoE-VIKOR) were successfully applied to assess 145 gully locations and 15 environmental factors, namely elevation, slope, aspect, plan curvature, stream power index (SPI), topography wetness index (TWI), rainfall, soil type, drainage density, distance to river, distance to road, distance to fault, lithology, land use/land cover (LU/LC), and normalized difference vegetation index (NDVI). Our results showed that the IoE and expert knowledge models considered soil type, lithology, elevation, and land use to have the biggest impact on gully occurrence in the study area. The validation of our results using the AUROC curve showed that IoE has a higher prediction accuracy than the other models. The scientific methodology presented in this study can be used in areas that do not have accurate data on the spatial distribution of past and current gullies. The results of this research could be used by environmental planners to manage and reduce the risks associated with the development of gully erosion in the study area as well as in the conservation of natural resources such as water and soil.

Author Contributions: Conceptualization, A.A.; Methodology, A.A.; formal analysis, A.A.; investigation, A.A., A.C., B.P., and D.T.B.; resources, A.A.; supervision, A.A.; writing-original draft preparation, A.A.; writing-review and editing, A.A., A.C., D.T.B., B.P., J.R.-C., T.B., and M.S.; funding acquisition, T.B.

Funding: This research was partly funded by the Austrian Science Fund (FWF) through the Doctoral College GIScience (DK W 1237-N23) at the University of Salzburg.

Acknowledgments: The authors would like to thank the Assistant Editor (Jeanne Zhou) and three anonymous reviewers for their helpful comments on the primary version of the manuscript.

Conflicts of Interest: The authors declare no conflict of interest.

\section{References}

1. Mekonnen, M.; Keesstra, S.D.; Baartman, J.E.; Stroosnijder, L.; Maroulis, J. Reducing sediment connectivity through man-made and natural sediment sinks in the Minizr Catchment, Northwest Ethiopia. Land Degrad. Dev. 2017, 28, 708-717. [CrossRef]

2. Ben Slimane, A.; Raclot, D.; Evrard, O.; Sanaa, M.; Lefevre, I.; Le Bissonnais, Y. Relative contribution of rill/interrill and gully/channel erosion to small reservoir siltation in Mediterranean environments. Land Degrad. Dev. 2015, 27, 785-797. [CrossRef] 
3. Ayele, G.K.; Gessess, A.A.; Addisie, M.B.; Tilahun, S.A.; Tebebu, T.Y.; Tenessa, D.B.; Steenhuis, T.S. A biophysical and economic assessment of a community-based rehabilitated gully in the Ethiopian highlands. Land Degrad. Dev. 2016, 27, 270-280. [CrossRef]

4. Castillo, C.; Marín-Moreno, V.J.; Pérez, R.; Muñoz-Salinas, R.; Taguas, E.V. Accurate automated assessment of gully cross-section geometry using the photogrammetric interface FreeXSapp. Earth Surf. Process. Landf. 2018, 43, 1726-1736. [CrossRef]

5. Pulley, S.; Ellery, W.N.; Lagesse, J.V.; Schlegel, P.K.; Mcnamara, S.J. Gully erosion as a mechanism for wetland formation: An examination of two contrasting landscapes. Land Degrad. Dev. 2018, 29, 1756-1767. [CrossRef]

6. Keesstra, S.; Mol, G.; de Leeuw, J.; Okx, J.; de Cleen, M.; Visser, S. Soil-related sustainable development goals: Four concepts to make land degradation neutrality and restoration work. Land 2018, 7, 133. [CrossRef]

7. Hosseinalizadeh, M.; Kariminejad, N.; Rahmati, O.; Keesstra, S.; Alinejad, M.; Behbahani, A.M. How can statistical and artificial intelligence approaches predict piping erosion susceptibility? Sci. Total Environ. 2019, 646, 1554-1566. [CrossRef]

8. Roscco, M.G.; Bull, L.G. Some factors controlling gully growth in fine grained sediment: A model applied in Southeast Spain. Catena 2000, 40, 127-146.

9. Arabameri, A.; Pradhan, B.; Lombardo, L. Comparative assessment using boosted regression trees, binary logistic regression, frequency ratio and numerical risk factor for gully erosion susceptibility modelling. Catena 2019, 183, 104223. [CrossRef]

10. Ireland, H.A.; Sharpe, C.F.; Eargle, D.H. Principles of Gully Erosion in the Piedmont of South Carolina; Technical Bulletin 633 USDA; United States Department of Agriculture: Washington, DC, USA, 1939.

11. Brice, J.B. Erosion and deposition in loess-mantled Great Plains, Medecine Creek Drainage Basin, Nebraska. Geol. Surv. Prof. 1966, 235-339.

12. Hauge, C. Soil erosion definitions. Calif. Geol. 1977, 30, 202-203.

13. Imeson, A.C.; Kwaad, F.J.P.M. Gully types and Gully prediction. Geogr. Tijdschr. 1980, 14, 430-441.

14. Poesen, J.; Vandaele, K.; Wesemael, B. Contribution of gully erosion to sediment production in cultivated lands and rangelands. Eros. Sediment. Yield Glob. Reg. Perspect. 1996, 236, 251-266.

15. Heed, B.H. Morphology of gullies in the Colorado Rocky Mountains. Bull. Int. Assoc. Sci. Hydrol. 1970, 2, 79-89. [CrossRef]

16. Morgan, R.P.C.; Mngomezulu, D. Threshold conditions for initiation of valley-side gullies in the Middle Veld of Swaziland. Catena 2003, 50, 401-414. [CrossRef]

17. Zaimes, G.N.; Schultz, R.C. Assessing riparian conservation land management practice impacts on gully erosion in Iowa. Environ. Manag. 2012, 49, 1009-1021. [CrossRef] [PubMed]

18. Valentin, C.; Poesen, J.; Li, Y. Gully erosion: Impacts, factors and control. Catena 2005, 63, 132-153. [CrossRef]

19. Brooks, K.N.; Ffolliott, P.F.; Gregersen, H.M.; DeBano, L.F. Hydrology and the Management of Watersheds; Iowa State University Press: Ames, USA, 2003; p. 574.

20. Arabameri, A.; Pradhan, B.; Pourghasemi, H.R.; Rezaei, K.; Kerle, N. Spatial modelling of gully erosion using GIS and R programing: A comparison among three data mining algorithms. Appl. Sci. 2018, 8, 1369. [CrossRef]

21. Poesen, J.; Nachtergaele, J.; Verstraeten, G.; Valentin, C. Gully erosion and environment change: Importance and research needs. Catena 2003, 50, 91-133. [CrossRef]

22. Deng, Q.; Qin, F.; Zhang, B.; Wang, H.; Luo, M.; Shu, C.; Liu, H.; Liu, G. Characterizing the morphology of gully cross-sections based on PCA: A case of Yuanmou Dry-Hot Valley. Geomorphology 2015, 228, 703-713. [CrossRef]

23. Castillo, C.; Gómez, J.A. A century of gully erosion research: Urgency, complexity and study approaches. Earth Sci. Rev. 2016, 160, 300-319. [CrossRef]

24. Qilin, Y.; Jiarong, G.; Yue, W.; Bintian, Q. Debris flow characteristics and risk degree assessment in Changyuan Gully, Huairou District, Beijing. Procedia Earth Planet. Sci. 2011, 2, 262-271.

25. Moore, I.D.; Grayson, R.B.; Ladson, A.R. Digital terrain modelling: A review of hydrological, geomorphological, and biological applications. Hydrol. Process. 1991, 5, 3-30. [CrossRef]

26. Vaezi, A.R.; Abbasi, M.; Keesstra, S.; Cerdà, A. Assessment of soil particle erodibility and sediment trapping using check dams in small semi-arid catchments. Catena 2017, 157, 227-240. [CrossRef] 
27. Zakerinejad, R.; Maerker, M. Prediction of gully erosion susceptibilities using detailed terrain analysis and maximum entropy modeling: A case study in the Mazayejan Plain, Southwest Iran. Geogr. Fis. E Din. Quat. 2014, 37, 67-76.

28. Meliho, M.; Khattabi, A.; Mhammdi, N. A GIS-based approach for gully erosion susceptibility modelling using bivariate statistics methods in the Ourika watershed, Morocco. Environ. Earth Sci. 2018, 77, 655. [CrossRef]

29. Rahmati, O.; Tahmasebipour, N.; Haghizadeh, A.; Pourghasemi, H.R.; Feizizadeh, B. Evaluating the influence of geo-environmental factors on gully erosion in a semi-arid region of Iran: An integrated framework. Sci. Total Environ. 2017, 579, 913-927. [CrossRef]

30. Conforti, M.; Aucelli, P.P.; Robustelli, G.; Scarciglia, F. Geomorphology and GIS analysis formapping gully erosion susceptibility in the Turbolo streamcatchment (Northern Calabria, Italy). Nat. Hazards 2011, 56, 881-898. [CrossRef]

31. Azareh, A.; Rahmati, O.; Rafiei-Sardooi, E.; Sankey, J.B.; Lee, S.; Shahabi, H.; BinAhmad, B. Modelling gully-erosion susceptibility in a semi-arid region, Iran: Investigation of applicability of certainty factor and maximum entropy models. Sci. Total Environ. 2019, 655, 684-696. [CrossRef]

32. Zabihi, M.; Mirchooli, F.; Motevalli, A.; Darvishan, A.K.; Pourghasemi, H.R.; Zakeri, M.A.; Sadighi, F. Spatial modelling of gully erosion in Mazandaran Province, northern Iran. Catena 2018, 161, 1-13. [CrossRef]

33. Conoscenti, C.; Angileri, S.; Cappadonia, C.; Rotigliano, E.; Agnesi, V.; Märker, M. Gully erosion susceptibility assessment by means of GIS-based logistic regression: A case of Sicily (Italy). Geomorphology 2014, 204, 399-411. [CrossRef]

34. Dewitte, O.; Daoudi, M.; Bosco, C.; Eeckhaut, M. Predicting the susceptibility to gully initiation in data-poor regions. Geomorphology 2015, 228, 101-115. [CrossRef]

35. Kornejady, A.; Heidari, K.; Nakhavali, M. Assessment of landslide susceptibility, semi-quantitative risk and management in the Ilam dam basin, Ilam. Iran. Environ. Resour. Res. 2015, 3, 85-109.

36. Arabameri, A.; Pradhan, B.; Rezaei, K.; Yamani, M.; Pourghasemi, H.R.; Lombardo, L. Spatial modelling of gully erosion using Evidential Belief Function, Logistic Regression and a new ensemble EBF-LR algorithm. Land Degrad. Dev. 2018, 29, 4035-4049. [CrossRef]

37. Dube, F.; Nhapi, I.; Murwira, A.; Gumindoga, W.; Goldin, J.; Mashauri, D.A. Potential of weight of evidence modelling for gully erosion hazard assessment in Mbire District-Zimbabwe. Phys. Chem. Earth 2014, 67, 145-152. [CrossRef]

38. Pourghasemi, H.R.; Yousefi, S.; Kornejady, A.; Cerdà, A. Performance assessment of individual and ensemble data-mining techniques for gully erosion modeling. Sci. Total Environ. 2017, 609, 764-775. [CrossRef]

39. Kornejady, A.; Ownegh, M.; Bahremand, A. Landslide susceptibility assessment using maximum entropy model with two different data sampling methods. Catena 2017, 152, 144-162. [CrossRef]

40. Rahmati, O.; Tahmasebipour, N.; Haghizadeh, A.; Pourghasemi, H.R.; Feizizadeh, B. Evaluation of different machine learning models for predicting and mapping the susceptibility of gully erosion. Geomorphology 2017, 298, 118-137. [CrossRef]

41. Arabameri, A.; Rezaei, K.; Pourghasemi, H.R.; Lee, S.; Yamani, M. GIS-based gully erosion susceptibility mapping: A comparison among three data-driven models and AHP knowledge-based technique. Environ. Earth Sci. 2018, 77, 628. [CrossRef]

42. Conoscenti, C.; Agnesi, V.; Cama, M.; Alamaru Caraballo-Arias, N.; Rotigliano, E. Assessment of gully erosion susceptibility using multivariate adaptive regression splines and accounting for terrain connectivity. Land Degrad. Dev. 2018, 29, 724-736. [CrossRef]

43. Arabameri, A.; Pradhan, B.; Rezaei, K. Gully erosion zonation mapping using integrated geographically weighted regression with certainty factor and random forest models in GIS. J. Environ. Manag. 2019, 232, 928-942. [CrossRef]

44. Arabameri, A.; Pourghasemi, H.R. Spatial Modeling of Gully Erosion Using Linear and Quadratic Discriminant Analyses in GIS and R, 1st ed.; Pourghasemi, H.R., Gokceoglu, C., Eds.; Elsevier: Amsterdam, The Netherlands, 2019; p. 796.

45. Hosseinalizadeh, M.; Kariminejad, N.; Chen, W.; Pourghasemi, H.R.; Alinejad, M.; Behbahani, A.M.; Tiefenbacher, J.P. Gully headcut susceptibility modeling using functional trees, naïve Bayes tree, and random forest models. Geoderma 2019, 342, 1-11. [CrossRef] 
46. Samani, A.N.; Rad, F.T.; Azarakhshi, M.; Rahdari, M.R.; Rodrigo-Comino, J.; Samani, A.N.; Rad, F.T.; Azarakhshi, M.; Rahdari, M.R.; Rodrigo-Comino, J. Assessment of the sustainability of the territories affected by gully head advancements through aerial photography and modeling estimations: A case study on Samal Watershed, Iran. Sustainability 2018, 10, 2909. [CrossRef]

47. Keesstra, S.; Nunes, J.P.; Saco, P.; Parsons, T.; Poeppl, R.; Masselink, R.; Cerdà, A. The way forward: Can connectivity be useful to design better measuring and modelling schemes for water and sediment dynamics? Sci. Total Environ. 2018, 644, 1557-1572. [CrossRef]

48. I.R. of Iran Meteorological Organization (IRIMO). Available online: http://www.mazandaranmet.ir. (accessed on 12 October 2017).

49. Soil Survey Staff. Keys to Soil Taxonomy, 12th ed; USDA-Natural Resources Conservation Service: Washington, DC, USA, 2014.

50. Geology Survey of Iran (GSI). Available online: http://www.gsi.ir/Main/Lang_en/index.html (accessed on 12 October 2017).

51. Arabameri, A.; Pradhan, B.; Rezaei, K. Spatial prediction of gully erosion using ALOS PALSAR data and ensemble bivariate and data mining models. Geosci. J. 2019, 1-18. [CrossRef]

52. Arabameri, A.; Cerda, A.; Tiefenbacher, J.P. Spatial pattern analysis and prediction of gully erosion using novel hybrid model of entropy-weight of evidence. Water 2019, 11, 1129. [CrossRef]

53. Arabameri, A.; Pradhan, B.; Rezaei, K.; Conoscenti, C. Gully erosion susceptibility mapping using GIS-based multi-criteria decision analysis techniques. CATENA 2019, 180, 282-297. [CrossRef]

54. Moore, I.D.; Burch, G.J.; Mackenzie, D.H. Topographic effects on the distribution of surface soil water and the location of ephemeral gullies. Am. Soc. Agric. Eng. 1988, 31, 1098-1107. [CrossRef]

55. Yesilnacar, E.K. The application of computational intelligence to landslide susceptibility mapping in Turkey. Ph.D. Thesis, Department of Geomatics the University of Melbourne, Melbourne, Australia, March 2005.

56. Yufeng, S.; Fengxiant, J. Landslide stability analysis based on generalized information entropy. Int. Conf. Environ. Sci. Inf. Appl. Technol. 2009, 83-85.

57. Pourghasemi, H.R.; Mohammady, M.; Pradhan, B. Landslide susceptibility mapping using index of entropy and conditional probability models in GIS: Safarood Basin, Iran. Catena 2012, 97, 71-84. [CrossRef]

58. Haghizadeh, A.; Siahkamari, S.; Haghiabi, A.H.; Rahamti, O. Forecasting flood-prone areas using Shannon's entropy model. J. Earth Syst. Sci. 2017, 126, 39. [CrossRef]

59. Arabameri, A.; Pourghasemi, H.R.; Cerda, A. Erodibility prioritization of sub-watersheds using morphometric parameters analysis and its mapping: A comparison among TOPSIS, VIKOR, SAW, and CF multi-criteria decision. Sci. Total Environ. 2018, 613, 1385-1400. [CrossRef] [PubMed]

60. Arabameri, A. Application of the Analytic Hierarchy Process (AHP) for locating fire stations: Case study Maku City. Merit Res. J. ArtSoc. Sci. Humanit. 2014, 2, 1-10.

61. Arabameri, A.; Rezaei, K.; Cerdà, A.; Conoscenti, C.; Kalantari, Z. A comparison of statistical methods and multi-criteria decision making to map flood hazard susceptibility in Northern Iran. Sci. Total Environ. 2019, 660, 443-458. [CrossRef]

62. Arabameri, A.; Rezaei, K.; Cerda, A.; Lombardo, L.; Rodrigo-Comino, J. GIS-based groundwater potential mapping in Shahroud plain, Iran. A comparison among statistical (bivariate and multivariate), data mining and MCDM approaches. Sci. Total Environ. 2019, 658, 160-177. [CrossRef]

63. Arabameri, A.; Pradhan, B.; Pourghasemi, H.R.; Rezaei, K. Identification of erosion-prone areas using different multi-criteria decision-making techniques and GIS. Geomat. Nat. Hazards Risk 2018, 9, 1129-1155. [CrossRef]

64. Arabameri, A.; Ramesht, M.H. Site Selection of Landfill with emphasis on Hydrogeomorphologicalenvironmental parameters Shahrood-Bastam watershed. Sci. J. Manag. Syst. 2017, 16, 55-80.

65. Yamani, M.; Arabameri, A. Comparison and evaluation of three methods of multi attribute decision making methods in choosing the best plant species for environmental management (Case study: Chah Jam Erg). Nat. Environ. Chang. 2015, 1, 49-62.

66. Arabameri, A. Zoning Mashhad Watershed for artificial recharge of underground aquifers using topsis model and GIS technique. Global J. Hum. Soc. Sci. B Geogr. Geo Sci. Environ. Disaster Manag. 2014, 14, 45-53.

67. Chen, L.Y.; Wang, T.C. optimizing partners'choice in IS/IT outsourcing projects: The strategic decision of fuzzy VIKOR. Int. J. Prod. Econ. 2009, 120, 55-79. [CrossRef] 
68. Opricovic, S.; Tzeng, G. Extended VIKOR method in comparison with outranking methods. Eur. J. Oper. Res. 2006, 178, 514-529. [CrossRef]

69. Romer, C.; Ferentinou, M. Shallow landslide susceptibility assessment in a semi-arid environment A Quaternary catchment of KwaZulu-Natal, South Africa. Eng. Geol. 2016, 201, 29-44. [CrossRef]

70. Tien Bui, D.; Hoang, N.D.; Martínez-Álvarez, F.; Ngo, P.T.T.; Hoa, P.V.; Pham, T.D.; Samui, P.; Costache, R. A novel deep learning neural network approach for predicting flash flood susceptibility: A case study at a high frequency tropical storm area. Sci. Total Environ. 2019. [CrossRef]

71. O'Brien, R.M. A caution regarding rules of thumb for variance inflation factors. Qual. Quant. 2007, 41, 673-690. [CrossRef]

72. Rahmati, O.; Haghizadeh, A.; Pourghasemi, H.R.; Noormohamadi, F. Gully erosion susceptibility mapping: The role of GIS based bivariate statistical models and their comparison. Nat. Hazards 2016, 82, 1231-1258. [CrossRef]

73. Arabameri, A.; Yamani, M.; Pradhan, B.; Melesse, A.; Shirani, K.; Tien Bui, D. Novel ensembles of COPRAS multi-criteria decision-making with logistic regression, boosted regression tree, and random forest for spatial prediction of gully erosion susceptibility. Sci. Total Environ. 2019, 688, 903-916. [CrossRef]

74. Mohammadkhan, S.; Ahmadi, H.; Jafari, M. Relationship between soil erosion, slope, parent material, and distance to road (Case study: Latian Watershed, Iran). Arab. J. Geosci. 2011, 4, 331-338. [CrossRef]

75. Nazari Samani, A.; Khosravi, H.; Mesbahzadeh, T.; Azarakhshi, M.; Rahdari, M.R. Determination of sand dune characteristics through geomorphometry and wind data analysis in central Iran (Kashan Erg). Arab. J. Geosci. 2016, 9, 716. [CrossRef]

76. Cerdà, A. Soil water erosion on road embankments in eastern Spain. Sci. Total Environ. 2007, 378, 151-155. [CrossRef]

77. Yousefi, S.; Sadeghi, S.H.; Mirzaee, S.; Ploeg, M.; Keesstra, S.; Cerdà, A. Spatio-temporal variation of throughfall in a hyrcanian plain forest stand in Northern Iran. J. Hydrol. Hydromech. 2018, 66, 97-106. [CrossRef]

78. García-Ruiz, J.; Lasanta, T.; Alberto, F. Soil erosion by piping in irrigated fields. Geomorphology 1997, 20, 269-278. [CrossRef]

79. Romero Díaz, A.; Marín Sanleandro, P.; Sánchez Soriano, A.; Belmonte Serrato, F.; Faulkner, H. The causes of piping in a set of abandoned agricultural terraces in southeast Spain. Catena 2007, 69, 282-293. [CrossRef]

80. Bravo-Espinosa, M.; Mendoza, M.E.; Carlón Allende, T.; Medina, L.; Sáenz-Reyes, J.T.; Páez, R. Effects of converting forest to avocado orchards on topsoil properties in the trans-Mexican volcanic system, Mexico. Land Degrad. Dev. 2014, 25, 452-467. [CrossRef]

81. Ben Slimane, A.; Raclot, D.; Rebai, H.; Le Bissonnais, Y.; Planchon, O.; Bouksila, F. Combining field monitoring and aerial imagery to evaluate the role of gully erosion in a Mediterranean catchment (Tunisia). Catena 2018, 170, 73-83. [CrossRef]

82. Yitbarek, T.W.; Belliethathan, S.; Stringer, L.C. The onsite cost of gully erosion and cost-benefit of gully rehabilitation: A case study in Ethiopia. Land Degrad. Dev. 2012, 23, 157-166. [CrossRef]

83. Ramakrishna, D.; Ghose, M.K.; Vinu Chandra, R.; Jeyaram, A. Probabilistic techniques, GIS and remote sensing in landslide hazard mitigation: A case study from Sikkim Himalayas, India. Geocarto Int. 2005, 20, 53-58. [CrossRef]

84. Sharma, L.P.; Patel, N.; Ghose, M.K.; Debnath, P. Influence of Shannon's entropy on lands lide-Causing parameters for vulnerability study and zonation-a case study in Sikkim, India. Arab. J. Geosci. 2010, 5, 421-431. [CrossRef]

(C) 2019 by the authors. Licensee MDPI, Basel, Switzerland. This article is an open access article distributed under the terms and conditions of the Creative Commons Attribution (CC BY) license (http://creativecommons.org/licenses/by/4.0/). 